Draft, Feb. 24, 2012. Please do not cite or circulate without permission.

\title{
The Social Cost of Financial MisRePresentations
}

\author{
Urska Velikonja*
}

\begin{abstract}
Policy makers, regulators, and academics have traditionally looked for the harm from securities fraud in the easy-to-study financial markets. However, by doing so, they have missed the significantly larger social welfare losses caused by securities fraud that fall outside financial markets. False financial disclosures, which are the most common variant of securities fraud, distort real economic decisions that firms, their rivals, suppliers, vendors, lenders, and workers make, thus distorting markets for inputs and outputs. When the fraud is revealed, every party affected makes costly adjustments. Many fraud-committing firms file for bankruptcy. Their rivals face doubts, called contagion. All firms must adjust their business operations to the new (accurate) information, and they often pass on the cost to their employees, suppliers, and customers. Significantly, the cost to non-shareholders dwarfs that suffered by shareholders.

As a result, securities regulation and enforcement predicated on the assumption that financial misrepresentations harm only investors will result in worse disclosures and more fraud than is socially optimal. Because the cost of fraudulent disclosures is dispersed and may be difficult to quantify with sufficient precision, private remedies against fraud are inevitably ineffective. Instead, honest disclosures have the characteristics of a public good. And so, public regulation directed at prevention and early detection, coupled with public enforcement actions against individual wrongdoers, is the welfare enhancing.
\end{abstract}

* @ 2012 Urska Velikonja, Assistant Professor of Law, University of Maryland Francis King Carey School of Law. J.D. Harvard; LL.M. Harvard; LL.B. University of Ljubljana. The Article was selected in a competitive call for papers for presentation at the C-LEAF Junior Business and Financial Law Workshop at George Washington University, where it was also awarded a Junior Faculty Scholarship Prize. I would like to thank Jennifer Arlen, Peter Conti-Brown, Cynthia Glassman, Michelle Harner, Joan MacLeod Heminway, Christine Hurt, Ira Lindsay, Robert Rhee, Ganesh Sitaraman, Max Stearns, Joseph Yockey, and participants of the faculty workshop at Villanova University School of Law and the Junior Faculty Workshop at the University of Maryland Francis King Carey School of Law for their thoughtful comments. Any misleading, incorrect, or incomplete disclosures remain the responsibility of the author, to the extent they are material. 


\section{TABLE OF CONTENTS}

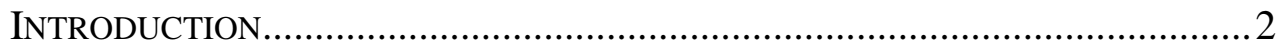

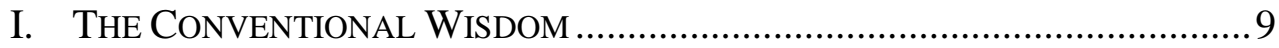

II. THE BIGGER PICTURE ....................................................................... 15

A. Financial Misrepresentations and Market Distortion .................. 15

B. Empirical Evidence on the Cost of Financial Misrepresentations .20

1. Intra-firm Cost ................................................................................ 21

a. Cost to Shareholders in the Fraud Firm .............................2 21

b. Cost to Non-Shareholders ................................................22

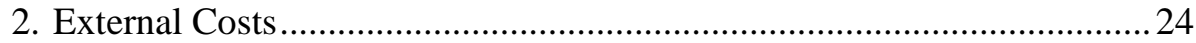

a. Equity Market Effects ......................................................24

b. Debt Market Cost ............................................................ 27

c. Labor Market Cost .............................................................29

d. Cost to Product Markets.......................................................... 32

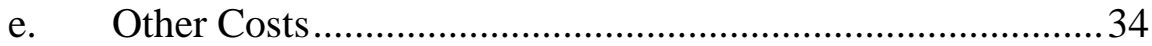

C. Determinants of the Social Cost's Magnitude....................................34

1. Likelihood of Fraud ................................................................................... 35

2. Size of the Distortion from Fraud ............................................................... 36

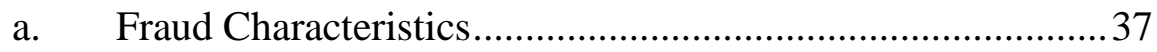

b. Fraud Firm Characteristics .................................................. 38

c. Market Characteristics ........................................................ 38

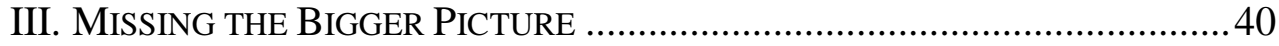

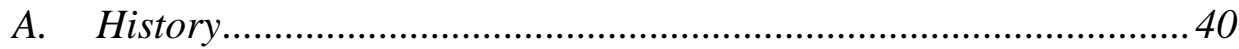

B. The Changed Nature of Securities Fraud ...................................... 41

C. Blinders of the Discipline ............................................................... 43

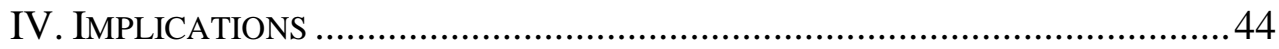

A. Implications for Fraud Prevention, Regulation, and Enforcement 45

A. Implications for Competing Theories of the Firm ......................... 54

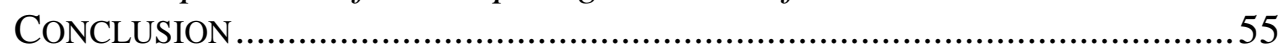

\section{INTRODUCTION}

Financial manipulation at WorldCom destroyed tens of billions of dollars in investors' equity and pushed the firm into bankruptcy. ${ }^{1}$ When it emerged two years later as MCI, Inc., it had shed 33,000 employees, more

\footnotetext{
${ }^{1}$ Before fraud was unmasked, WorldCom was one of the largest telecommunications companies with $\$ 160$ billion in assets. In a class action settlement, WorldCom's shareholders ultimately recovered $\$ 6.1$ billion. Ken Belson, WorldCom's Audacious Failure and Its Toll on an Industry, N.Y. TIMES, Jan. 18, 2005, at C1.
} 
than a third of its workforce. ${ }^{2}$ Its general unsecured creditors ultimately received only 36 cents on the dollar. ${ }^{3}$ While WorldCom was fabricating its financials, its rivals, Sprint and AT\&T, made business decisions on the supposition that WorldCom's success was real. Under pressure from its own shareholders, AT\&T cut $\$ 7.5$ billion in costs and laid off 20,000 employees. Still unable to compete with WorldCom's figures, AT\&T split itself into three units, which were sold individually - a decision then, and now, widely viewed as value destroying. In fact, during all that time, WorldCom's true costs were higher than AT\&T's. ${ }^{4}$ Telecommunication equipment manufacturers, including Lucent Technologies and Nortel Networks, initially benefitted from WorldCom's apparent success, but suffered when the industry retrenched after the fraud was revealed. Both suppliers fired workers and saw their equity shrink. ${ }^{5}$ In the aftermath of the WorldCom fraud, the telecommunications industry as a whole lost 300,000 jobs (out of 1.3 million). ${ }^{6}$ WorldCom's share price, the usual yardstick for measuring harm from securities fraud, captured none of these harms.

WorldCom may have been an unfortunate outlier, but it is hardly unique. During the fraud, managers sell the lie by hiring and investing more and cutting prices. Goosed hiring, excessive investment and prices too low distort every market they touch. Creditors underprice credit, employees make career and retirement decisions based on a false picture of their employer's prospects, and rivals make business decisions on a distorted playing field. ${ }^{7}$ After disclosing accounting improprieties, many firms file for bankruptcy, fire workers, repudiate debts, and close operations, harming their suppliers and customers.

\footnotetext{
${ }^{2}$ See Steve Alexander, Former Holders of MCI Stock Miss Out: The Bidding War for MCI Will Enrich the Firm's Shareholders - the Current Ones, STAR TRIBUNE, May 1, 2005, at D1.

${ }^{3}$ See Official Comm't of Unsecured Creditors of WorldCom v. SEC, 467 F.3d 73, 8485 (2d Cir. 2006) (observing that general unsecured creditors recovered 36 cents on the dollar and limiting the distribution of the SEC Fair Fund proceeds to those investors who have recovered less)

${ }^{4}$ Rebecca Blumenstein \& Peter Grant, On the Hook: Former Chief Tries to Redeem Calls He Made at AT\&T, WALL ST. J., May 26, 2004, at A1. See also Sadka, supra note 81, at 459-60 (showing that AT\&T and Sprint performed much better than WorldCom between 1999 and 2002, the period of fraud).

5 Edward J. Romar \& Martin Calkins, WorldCom Case Study Update, http://www.scu.edu/ethics/dialogue/candc/cases/worldcom-update.html/.

${ }^{6}$ Alexander, supra note 2, at D1.

7 See Cynthia A. Glassman, Speech by SEC Commissioner: Financial Reform: Relevance and Reality in Financial Reporting, Sept. 16, 2003, http://www.sec.gov/news/ speech/spch091603cag.htm.
} 
Without doubt, financial misrepresentations ${ }^{8}$ harm more than just investors. But one would not know that from looking at the nature of our securities laws, from statutes to rulemaking, ${ }^{9}$ from enforcement decisions to judicial opinions, ${ }^{10}$ from policy debates ${ }^{11}$ to academic analysis. ${ }^{12}$ This Article argues that the fundamental assumption of securities regulation and enforcement is wrong. A growing body of accounting literature shows that financial misrepresentations affect business decisions by firms and their rivals, and thereby distort markets for both inputs and outputs. The ripple effects of the distortion are felt throughout the economy and, once aggregated, exceed the harms to defrauded shareholders by a substantial margin. $^{13}$

WorldCom, Enron, and their unfortunate sisters-in-crime roused regulators from their slumber, and financial misrepresentations received more attention. Enforcement included many highly-publicized criminal prosecutions against both firms and their managers. After Enron's audit firm, Arthur Andersen, was indicted and filed for bankruptcy, and a number of executives received long prison sentences, critics - the U.S. Chamber of Commerce, ${ }^{14}$ the American Bar Association, ${ }^{15}$ the Business Roundtable, ${ }^{16}$

${ }^{8}$ The Article uses the terms financial misrepresentations, fraud, accounting fraud, and fraudulent disclosures interchangeably to refer to fraud, not mere inaccuracy in reported financial statements.

9 The Securities Exchange Act authorizes the SEC to consider the "public interest" in rulemaking, defining it as "whether the action will promote efficiency, competition, and capital formation.” 15 U.S.C. $\$ 78 \mathrm{c}(\mathrm{f})$.

${ }^{10}$ See e.g., Blue Chip Stamps v. Manor Drug Stores, 421 U.S. 723, 729 (1975).

${ }^{11}$ See COMM'N ON THE REG. OF U.S. CAP. MKTS. IN THE $21^{\text {ST }}$ CENTURY, REPORT AND RECOMMENDATIONS (2007), at 12, available at http://www.uschamber.com/sites/default/ files/reports/0703capmarkets_full.pdf/ (concluding that the purposes of securities regulation are investor protection and fostering capital formation).

12 The most commonly used securities regulation textbook begins its first chapter: "The securities laws exist because of the unique informational needs of investors." JAMES D. Cox, Robert W. Hillman \& Donald C. Langevoort, Securities Regulation: CASES AND MATERIALS 1 (6th ed. 2009).

${ }^{13}$ See Art Durnev \& Claudine Mangen, Corporate Investments: Learning from Restatements, 47 J. ACCT. RES. 679, 699 (2009) (finding that costs to rivals exceed those to investors in restating firms by a factor of four); Eitan Goldman, Irina Stefanescu \& Urs Peyer, Financial Misrepresentation and Its Impact on Rivals, 27 \& fig. 3, http://ssrn.com/ abstract $=774364 /$ (suggesting that the aggregate stock price decline by rivals exceeds the loss to fraud firms by nearly an order of magnitude).

14 See U.S. CHAMBER OF COMMERCE, REPORT ON THE CURRENT ENFORCEMENT Program of THE SECURITIES AND EXCHANGE COMMISSION 2 (Mar. 2006), available at http://www.uschamber.com/sites/default/files/reports/0603secenforcementstudy.pdf/ (suggesting that the SEC had adopted an "overly punitive approach to enforcement").

15 See ABA AtTorney-CliEnt Privilege TASK Force, Report to ABA House of DELEGATES ON EMPLOYEE RIGHTS 17 (2006) (arguing that civil and criminal enforcement 
various congressmen, ${ }^{17}$ mayors, ${ }^{18}$ and academics ${ }^{19}$ - expressed concern that the pendulum had swung too far. The most articulate of these contended that the costs of securities regulation and enforcement exceeded the purported benefits. ${ }^{20}$ They worried that "corporate leaders were focusing inordinate time on compliance minutiae rather than on innovative strategies for growth," 21 and that U.S. capital markets were suffering under the weight of costly regulation. ${ }^{22}$

The same sentiment appears to have reduced the Securities and Exchange Commission's ("SEC") and Department of Justice's ("DOJ") ${ }^{23}$ appetite for vigorous enforcement of the accounting improprieties discovered during the 2008-09 financial crisis. ${ }^{24}$ The court-appointed

actions against fraud harmed firms, eroded individuals' constitutional rights, and undermined the role of lawyers).

${ }^{16}$ See The Thompson Memorandum's Effect on the Right to Counsel in Corporate Investigation Before the S. Comm. on the Judiciary, 109th Cong. (2006), available at http://judiciary.senate.gov/hearing.cfm?id=2054/ (statement of Karen J. Mathis, President, American Bar Association) (listing the Business Roundtable among the organizations critical of corporate prosecutions).

${ }^{17}$ See e.g., Charles E. Schumer \& Michael R. Bloomberg, To Save New York, Learn from London, at A18, WALL ST. J., Nov. 1, 2006.

${ }^{18} I d$.

${ }^{19}$ See e.g., Miriam H. Baer, Insuring Corporate Crime, 83 IND. L.J. 1035, 1063 (2008) (arguing that firms generally overpay for fraud); John C. Coffee, Jr., Reforming the Securities Class Action: An Essay on Deterrence and Its Implementation, 106 Colum. L. REV. 1534, 1534 (2006) [hereinafter Coffee, Reforming] (naming the U.S. Chamber of Commerce as a powerful advocate for this position); Brandon L. Garrett, Structural Reform Prosecution, 93 VA. L. REV. 853 (2007) (arguing that imposing structural changes on corporations investigated for criminal fraud may be inefficiently costly); Donald C. Langevoort, Capping Damages for Open-Market Securities Fraud, 38 ARIZ. L. REv. 639, 646-47 (1996) (proposing damage caps in securities fraud class actions to reduce the amount of overpayment); Roberta Romano, The Sarbanes-Oxley Act and the Making of Quack Corporate Governance, 114 YALE L.J. 1521 (2005) (condemning the act as overly costly) [hereinafter Romano, Quack Corporate Governance]

${ }^{20}$ See id. See also Merrill Lynch, Pierce, Fenner \& Smith Inc. v. Dabit, 547 U.S. 71, 81-82 (2006).

${ }^{21}$ Schumer \& Bloomberg, supra note 17, at A18.

${ }^{22}$ COMM'N ON THE REg. OF U.S. CAP. MKTS. IN THE $21^{\text {ST }}$ CENTURY, supra note 11.

${ }^{23}$ The DOJ, which was very active after the accounting scandals of 2001-02, has been uninterested in prosecuting financial misrepresentations uncovered during the recent financial crisis. Instead, it has directed its resources toward prosecuting mortgage originators for fraud, more than doubling the number of cases brought and defendants charged from 2009 to 2010. FinANCIAL FRAUd ENFORCEMENT TASK FORCE, FiRST YEAR REPORT 2010, at 3.5, 3.7-3.8, available at http://www.stopfraud.gov/docs/ FFETF-ReportLR.pdf/.

${ }^{24}$ The SEC has investigated and sanctioned a handful of firms for accounting fraud during the 2008 financial crisis, but overall its efforts have been modest. See Securities \& Exchange Comm'n, SEC Enforcement Actions: Addressing Misconduct That Led to or 
examiner found serious accounting violations at Lehman Brothers, including understated liabilities of more than $\$ 50$ billion $^{25}$ (compare this with WorldCom, which hid $\$ 12$ billion in losses). ${ }^{26}$ Yet, the SEC has not yet initiated an enforcement action against the firm or any individual involved. The SEC defended its reticence by explaining that it was not convinced "that Lehman shareholders suffered material harm" from the misstatement, without considering whether non-shareholders may have been harmed. ${ }^{27}$

Sarbanes-Oxley Act and enforcement following the accounting scandals of 2001-02 prompted many to study the purported cost of compliance, and to argue that it is excessive. ${ }^{28}$ But the benefit of reducing fraudulent disclosures has received considerably less attention. ${ }^{29}$ This is largely

Arose From the Financial Crisis, http://www.sec.gov/spotlight/enf-actions-fc.shtml/ (last visited Feb. 22, 2012) (reporting a \$75 million settlement with Citigroup and a \$22.5 million settlement with the CEO of Countrywide, Angelo Mozillo, for accounting manipulations). Overall, the SEC has charged 49 senior corporate officials and sanctioned 25 for fraud arising from the financial crisis of 2008. Compare that with the efforts of DOJ's Corporate Fraud Task Force after the fraud scandals of 2001-02 that, within seven years, secured over 1,300 convictions, including of "more than 200 chief executive officers and presidents, more than 120 corporate vice presidents, and more than 50 chief financial officers." Dep't of Justice, President's Corporate Fraud Task Force Adds Six New Member Agencies, Jan. 6, 2009, available at http://www.usdoj.gov/opa/pr/2009/January/ 09-odag003.html/.

${ }^{25}$ See Report of Anton R. Valukas, Examiner, In re Lehman Brothers Holdings, Inc., 08-13555 (Mar. 11, 2010), at 739 ("Lehman temporarily reduced its net balance sheet at quarter-end through its Repo 105 practice by approximately $\$ 38.6$ billion in fourth quarter 2007, \$49.1 billion in first quarter 2008, and $\$ 50.38$ billion in second quarter 2008.”).

${ }^{26}$ Joseph Bower \& Stuart Gilson, The Social Cost of Fraud and Bankruptcy, HARV. Bus. REV., Dec. 2003, at 20, 20.

27 Jean Eaglesham \& Liz Rappaport, Lehman Probe Stalls; Chance of No Charges, WALL ST. J., Mar. 1, 2011, at B1 (emphasis added).

${ }^{28}$ See e.g., Stephen M. Bainbridge, Sarbanes-Oxley: Legislating in Haste, Repenting in Leisure, 2 CORP. GOVERnANCE L. REV. 69 (2006) (criticizing the law because it increased the costs of corporate compliance); Larry E. Ribstein, Sarbox: The Road to Nirvana, 2004 Mich. ST. L. REV. 279, 280-81 (2004); Romano, Quack Corporate Governance, supra note 20 (arguing that the Sarbanes-Oxley Act was unnecessary); Ivy Zhang, Economic Consequences of the Sarbanes-Oxley Act of 2002, http://papers.ssrn.com/sol3/papers.cfm?abstract_id= 961964/ (arguing that SOX cost U.S. equity markets $\$ 1.4$ trillion).

${ }^{29}$ See William W. Bratton \& Michael L. Wachter, The Political Economy of Fraud on the Market, 160 U. PA. L. REV. 69, 117 (2011) [hereinafter Bratton \& Wachter, FOTM] ("Scholars have written about the costs of Sarbanes-Oxley's new regime, but we are aware of no significant scholarship on the benefits of increased compliance.") (citation omitted); John C. Coates IV, The Goals and Promise of the Sarbanes-Oxley Act, 21 J. ECON. PERSP. 91, 91-92 (2007) (evaluating the costs as well as the benefits of the Sarbanes-Oxley Act); Herbert Hovenkamp, Antitrust's Protected Classes, 88 MicH. L. REV. 1, 2 (1989) 
because the underlying questions about the size and the incidence of the cost of securities fraud are considered to be all but resolved. The consensus view is that the social cost from any single incident of fraud is negligible (or on net small) and borne almost entirely by defrauded shareholders, who also bear the brunt of any sanctions imposed on firms after truth is revealed. ${ }^{30}$

But, this Article shows that financial misrepresentations harm nonshareholders, both while the fraud is ongoing and thereafter. Compliance imposes costs on honest and dishonest firms alike. But fraud, likewise, harms honest and dishonest firms. With all costs known and accounted for, the following conclusions are inescapable: (1) financial misrepresentations affect financial markets as well as markets for inputs, labor and credit, and product markets; (2) framing accounting fraud as solely securities fraud understates the social harms caused by it; and (3) regulation and enforcement predicated on the assumption that accounting fraud does not impose negative externalities on non-shareholders will underdeter. ${ }^{31}$ If the estimates of the social cost of financial misrepresentations and their incidence are correct, then much of the received wisdom about securities fraud deterrence, the incentives of investors to prevent fraud, the costeffectiveness of existing regulation, the balance between public and private enforcement, the "vexatiousness" of securities fraud class actions, ${ }^{32}$ and the need to reign in "overreaching prosecutors" must be re-evaluated. ${ }^{33}$

In Part I, the Article recounts the conventional wisdom on securities fraud deterrence. In Part II, the Article explains analytically how financial misrepresentations distort non-financial markets. It then marches through empirical evidence market-by-market, and suggests that the costs of financial misstatements have been grossly understated in the existing literature. Finally, it suggests that the size of the distortion depends largely on the duration of fraud, firm size, and competition in product markets. In addition to making fraud more likely, imperfect competition also enables

(explaining that sanctions are costly, but may be efficient if they reduce the number and/or cost of violations).

${ }^{30}$ See e.g., COX, HILlMAN \& LANGEVOORT, supra note 12, AT 727-29 (citing more than a dozen scholarly articles expressing the consensus view).

${ }^{31}$ Even if the cost calculus is adjusted, enforcement strategies might still underdeter when the sanction is placed on the firm if the firm cannot effectively shift it to deter the individuals who commit fraud. See e.g., Urska Velikonja, Leverage, Sanctions, and Deterrence of Accounting Fraud, 44 U.C. DAVIS L. REV. 1281 (2011).

${ }^{32}$ Blue Chip Stamps v. Manor Drug Stores, 421 U.S. 723, 739 (1975).

${ }^{33}$ United States v. Ataya, 864 F.2d 1324, 1330 n.9 (7th Cir. 1988) ("A pre-indictment hearing would help prevent overreaching by prosecutors . . . in the drafting of ambiguous plea agreements."); Baer, supra note 20, at 1062; Preet Bharara, Corporations Cry Uncle And Their Employees Cry Foul: Rethinking Prosecutorial Pressure On Corporate Defendants, 44 AM. CRIM. L. REV. 53, 55 (2007). 
managers to shield profits and protect the stock price by shifting the costs of fraud onto customers, employees, suppliers. In Part III, the Article provides possible explanations for the blindness of commentators to the full social cost of financial misrepresentations, including history, innovation in wrongdoing, and intellectual path dependence. Finally, in Part IV, the Article describes the implications of this research. Specifically, the Article argues that shareholders do not have optimal incentives to prevent financial misrepresentations. Because the social cost of misrepresentations is dispersed and difficult to measure in each case, our best bet to reduce fraud to the socially optimal level might be substantial sanctions against individual wrongdoers coupled with ex ante regulation designed to improve the quality of disclosures.

The Article focuses on financial misrepresentations because, at least over the last decade, they are the most common species in the menagerie of securities fraud. ${ }^{34}$ Hence, virtually all relevant empirical work has studied the effect of financial misrepresentations. But, other inaccurate disclosures on which market participants rely can distort decision-making, ${ }^{35}$ producing ripple effects that ought to be taken into account when making policy and enforcement decisions, and designing regulation.

In addition, the Article focuses on misrepresentations, but relies in large part on studies that report effects of (mere) restatements, not just restatements accompanied by an enforcement action. Where studies report both, the effect of the latter is greater. ${ }^{36}$ This warrants two observations. First, social welfare losses accompany even entirely innocent misstatements. ${ }^{37}$ Second, measuring the effects of fraud by looking at all restating firms understates social welfare losses from fraud from each

34 See Securities Class Action Filings 2011: A Year in Review 28, fig. 26, CORNERSTONE RESEARCH, available at http://securities.stanford.edu/clearinghouse_ research/2011_YIR/Cornerstone_Research_Filings_2011_YIR.pdf/ (reporting that 94\% of class actions filed in 2011 alleged misrepresentations in financial documents, a percentage that has remained stable over the years).

35 See e.g., SEC v. Jos. Schlitz Brewing, 452 F.Supp. 824, 830 (E.D. Wis. 1978) (holding that misleading disclosures pertaining to managerial integrity were material); In the Matter of Franchard Corporation, 42 S.E.C. 163 (1964) (concluding that operating misstatements are material); Tom Baker \& Sean J. Griffith, Predicting Corporate Governance Risk: Evidence from the Directors' \& Officers' Liability Insurance Market, 74 U. CHI. L. REV. 487, 519-20 (observing that managers' character and firm culture increase the propensity for fraud)

${ }^{36}$ Durnev and Mangen report that aggregate stock-market losses to rivals are 4-times the size of losses suffered by the restating firm, while Goldman, Peyer, and Stefanescu find losses to rivals almost 10-times the size of losses to the fraud firm. See supra note 13.

${ }^{37}$ Some of the studies reported in Part II measure effects of mere restatements, others of restatements accompanied by enforcement actions. Although the effects of mere restatements are smaller, they are not negligible. See id. 
incident (assuming at least some restatements are innocent). ${ }^{38}$ Nevertheless, the normative arguments in this Article focus on fraudulent financial disclosures. But, in terms of harm caused by false disclosures, however, the relationship between fraud and a restatement is not one of black and white, but rather one of various shades of gray.

\section{The Conventional Wisdom}

According to the received wisdom, the purpose of regulation of, and liability for, fraudulent disclosures is deterrence. ${ }^{39}$ In order to deter optimally (not too much and not too little), the malefactor must "be confronted with the cost of his violation," 40 increased by the probability of avoiding detection and sanctioning. Otherwise, he will commit more fraud than is optimal, just like a chemical plant will produce too much pollution unless it is required to pay for the harm caused. ${ }^{41}$ Cost internalization can rarely be achieved without enforcement, which is by itself costly. No matter how large the social cost of fraud, the marginal cost of enforcement at some point exceeds the marginal benefit of fraud prevention. ${ }^{42}$ Therefore, the optimal level of fraud is not zero.

For optimal deterrence, regulatory and enforcement activity should strive to minimize the net social cost associated with fraud. To justify an extra dollar spent on enforcement, regulation and regulatory compliance

${ }^{38}$ Not all restatements suggest fraud, not all accounting frauds are followed by a restatement or an enforcement action. Using restatements alone overstates, but using enforcement actions understates fraud. Karpoff and his collaborators report that public enforcement actions accompany $40.2 \%$ of all restatements in their sample; they also note that many firms subject to an enforcement action do not survive long enough to file a restatement, and some simply ignore SEC's instruction to file a restatement. Jonathan M. Karpoff, D. Scott Lee \& Gerald S. Martin, The Cost to Firms of Cooking the Books, $43 \mathrm{~J}$. FIN. \& QUANTITATIVE ANALYSIS 581, 585 \& n.9 (2008).

39 See e.g., Coffee, Reforming, supra note 20, at 1547 (describing deterrence as a primary rationale in favor securities litigation, though the author subsequently expresses doubt about its effectiveness); Amanda M. Rose, The Multienforcer Approach to Securities Fraud Deterrence: A Critical Analysis, 158 U. PA. L. REV. 2173, 2178 (2010) [hereinafter Rose, Multienforcer Approach].

40 Richard A. POSNER, ECONOMIC ANAlysis OF THE LAW 349-50 (1972). It is irrelevant from the social welfare standpoint whether the violator pays the cost to the victims or into state coffers. Id.

${ }^{41}$ There is a strong argument in favor of penalizing intentional wrongs beyond the cost that they cause, to reinforce the social norm that wrongdoing is bad.

42 Thomas S. Ulen, The Economics of Corporate Criminal Liability, 17 MANAG. \& DEC. ECON. 351, 357-58 (1996). 
must save at least one dollar in fraud. ${ }^{43}$ The main advantage of the socialcost approach is that it focuses the analysis on why prevent wrongs in the first place: not only because they alter the distribution of wealth, but because that wealth transfer reduces social welfare as individuals change how they behave. The social cost of theft is not the value of the stolen necklace, but the cost of precautions taken to prevent burglaries, including buying heavier locks, handguns, or safe deposit boxes, and the opportunity cost of the reduced willingness to buy expensive jewelry in the first place. ${ }^{44}$

Before we can decide how much to deter a particular activity, we must decide how much of that activity we want, which requires determining the net social cost of the activity. Financial misrepresentations are generally understood as a species of fraud. In a plain vanilla case of fraud, a con artist defrauds a mark without any effect on a third party. Consider the apocryphal Brooklyn Bridge scam: a conman convinces a naïve immigrant that he owns the bridge with forged documents, and sells it for a princely sum of money. ${ }^{45}$ The con clearly has distributive effects - the involuntary transfer of value from the gullible victim to the conman - and also produces a social cost associated with enforcement. In a civil suit for compensatory damages, if she ever files it, the victim will only recover her private monetary cost from the particular incident, but not the net social cost of the fraud (let alone the net social cost multiplied by the probability of detection). As a result, punitive damages or criminal sanctions may be necessary to adequately deter such fraud. ${ }^{46}$

Financial misrepresentations in the secondary market for securities are often conceptualized as plain vanilla fraud, and the law has responded by providing defrauded shareholders a private right of action, in addition to

43 See Steven Shavell, Foundations of Economic AnAlysis of LAW 575-81 (2004) (discussing the determinants of the "optimal structure of legal intervention"); Stephen J. Choi \& Andrew T. Guzman, Portable Reciprocity: Rethinking the International Reach of Securities Regulation, 71 S. CAL. L. REV. 903, 916 (1998) ("Regulations impose a cost on issuers.... [F]or particular investors and issuers an optimal level of securities regulation exists."); Paul G. Mahoney, Precaution Costs and the Law of Fraud in Impersonal Markets, 78 VA. L. REV. 623, 626-27 (1992).

${ }^{44}$ See Gary Becker, Crime and Punishment: An Economic Approach, 76 J. PoL. ECON. 169, 207 (1968) (observing that the largest element of the social cost of crime is spent on precaution). Moreover, the thief values the necklace less than its owner (otherwise the thief would have gone to the store and bought it), so even the net transfer alone is not a wash.

${ }^{45}$ At least some believe the story is real. Gabriel Cohen, For You, Half Price, N.Y. Times, Nov. 27, 2005, at 4.

${ }^{46}$ See e.g., Ulen, supra note 42, at 360 (arguing that social costs of fraud justify imposing punitive sanctions). 
public enforcement. ${ }^{47}$ In a suit for damages, the defrauded shareholders allege that they bought stock based on managers' false statements. The prices paid were artificially inflated by material lies and omissions and so the defendants - the managers and the vicariously liable firm - ought to pay damages (and/or be appropriately sanctioned) for the harm the shareholders suffered.

But there are two important differences between plain vanilla fraud and financial misrepresentations in the secondary market that explain the opposition to fraud regulation and enforcement. First, investors can and do trade in stock in small increments. All investors have the ability to diversify their holdings and to trade frequently. Ex ante, they are as likely to be sellers as to be buyers, so, on average, their expected cost of fraud over time approximates zero, particularly in the absence of insider trading. ${ }^{48}$

Second, while a few insider defendants sell at prices inflated by fraud, most sellers are uninvolved and are allowed to keep the gain. ${ }^{49}$ Since defendants' gain is smaller than plaintiffs' losses, the shortfall must be made up, usually from shareholders who held on to their stock during fraud. ${ }^{50}$

If there is insider trading - and crooked managers often reduce their stockholdings while cooking the books ${ }^{51}$ - fraud will injure even diversified

${ }^{47}$ Kardon v. National Gypsum Co., 69 F. Supp. 512, 513-14 (E.D. Pa. 1946) (finding an implied private right of action to sue for damages). Kardon's holding was later adopted by "an overwhelming consensus of the District Courts and Courts of Appeals," Merrill Lynch, Pierce, Fenner \& Smith, Inc. v. Dabit, 547 U.S. 71, 79 (2006) (internal quotation marks omitted), and the U.S. Supreme Court in Superintendent of Insurance v. Bankers Life \& Casualty Co., 404 U.S. 6, 13 n.9 (1971). See also Anjan V. Thakor, Jeffrey S. Nielsen \& David A. Gulley, The Economic Reality of Securities Class Action Litigation, at 4 (observing that the securities fraud class action is based on the same principles and presumptions as a common law action for fraud).

${ }^{48}$ To quote Judge Posner, "Often the net measurable damages from a stock fraud will be zero." Richard A. Posner, Law and the Theory of Finance: Some Intersections, 54 GEO. WASH. L. REV. 159, 169 (1986). See also COX ET AL., supra note 12, at 728; Janet Cooper Alexander, Rethinking Damages in Securities Class Actions, 48 STAN. L. REV. 1487, 1502 (1996) (arguing that diversification and frequent trading effectively protects investors against securities fraud); Richard A. Booth, The End Of The Securities Fraud Class Action As We Know It, 4 BERKELEY Bus. L.J. 1, 10-11 (2007) (contending that investors can fully protect themselves from securities fraud losses by diversifying their holdings).

${ }^{49}$ Thakor et al., supra note 47 , at 4.

${ }^{50}$ Coffee suggests that buy-and-hold investors are the ones most likely to pay the damages from securities litigation; the beneficiaries are frequent traders, such as hedge funds. Coffee, Reforming, supra note 20, at 1560.

${ }_{51}$ See e.g., Simi Kedia \& Thomas Philippon, The Economics of Fraudulent Accounting, 22 REV. FIN. STUD. 2169, 2170 \& Fig.1 (2009) (noting that Enron insiders sold millions of dollars worth of Enron stock while fraud was ongoing, but billions in fact changed hands during that time). 
investors because insider trading transfers value from investors to insiders. But that transfer is much smaller than the aggregate decline in the price of affected stock, because insiders' sales represent only a small fraction of aggregate transactions in the stock. ${ }^{52}$ More importantly, a prudent investor diversifies anyway, so there is no incremental cost to diversify the risk of fraud. A number of commentators and courts have accepted that the measure of ill-gotten gains from insider trading is the net social cost of fraud. ${ }^{53}$

Others have acknowledged that social cost of fraud might be larger and include other cost categories. In his avowedly exhaustive list of the costs of securities fraud, Richard Posner notes that fraud produces three types of costs: what managers spend to conceal fraud, what investors spend to find fraud, and increased stock-market volatility-all costs that befall investors. $^{54}$

Frank Easterbrook and Daniel Fischel, likewise, contend that accounting fraud causes harms other than the net transfer from investors to insiders, but those harms, too, are largely borne by investors: the "total cost of carrying out the offense, unmasking the offense, taking precautions against similar offenses, and litigating about offenses." 55 They acknowledge that securities fraud might reduce the allocative efficiency of the economy, because it diverts resources from non-fraud firms to those that engage in fraud, and distorts the choice between investment and consumption. ${ }^{56}$ But, they conclude, without empirical support, that the social cost will be "small, and for many offenses the transfer of wealth [from shareholders to insiders] will be far and away the largest element of the net harm."57

Jennifer Arlen and Bill Carney observe that managers commit fraud when they fear for their jobs. Thus, fraud is an agency cost to the shareholders: they spend resources to monitor managers and to detect fraud,

52 Richard A. Booth, What Is a Business Crime?, 3 J. BuS. \& TECH. L. 127, 142-43 (2008) (arguing that absent insider trading, investor losses equal investor gains); Frank H. Easterbrook \& Daniel R. Fischel, Optimal Damages in Securities Cases, 52 U. CHI. L. REV. 611, $622(1985)$.

53 Alexander, supra note 48, at 1498 ("Aggregate class trading losses are probably greater than either the true net social cost of the violation or the benefits received by the violator, both of which are speculative in nature and difficult to calculate."); Adam C. Pritchard, Stoneridge Investment Partners v. Scientific-Atlanta: The Political Economy of Securities Class Actions, 2007-08 CATO SUP. CT. REV. 217, 219 (arguing that disgorgement of unlawful gains is the right measure of damages for securities fraud because it approximates the social costs of fraud) [hereinafter Pritchard, Stoneridge].

${ }^{54}$ Posner, supra note 48, at 170.

${ }^{55}$ Easterbrook \& Fischel, supra note 52, at 623.

${ }^{56} I d$.

${ }^{57}$ Id. at 625 . 
reduce their willingness to invest in the stock market for risk of fraud, and bear the cost of fraud enforcement. ${ }^{58}$

More recently, Paul Mahoney has acknowledged that securities fraud also sends inaccurate price signals that may induce inefficient transfers in both financial and real markets, including commodity, product, and labor markets. ${ }^{59}$ He ultimately dismisses the concern about the effects on the real economy and concludes that temporary mispricing of a security leads to small allocative costs, because it is irrelevant for the efficiency of capital markets who owns individual stocks. ${ }^{60}$

Finally, Marcel Kahan, in an attempt to provide a comprehensive overview of the social cost of inaccurate stock prices, focuses almost entirely on the social cost to financial markets, including reduced liquidity, increased risk, higher cost of capital, and impaired corporate governance. ${ }^{61}$ Kahan acknowledges that a rapid stock price decline can cause a macroeconomic shock, as consumers feel less wealthy and thus consume less, which lowers the rate of economic growth. ${ }^{62}$ Thus, if fraud causes a rapid stock-market decline, it might affect non-financial markets, but that effect will be indirect (rather than direct, as this Article suggests) and infrequent.

Despite a generation of increasing, and increasingly audacious, financial manipulation, followed by a substantial stock-market decline, a recession and a jobless recovery, ${ }^{63}$ scholarship has continued to focus solely on the effects of fraud (and fraud-prevention efforts) on financial markets. ${ }^{64}$ Even

58 Jennifer H. Arlen \& William J. Carney, Vicarious Liability for Fraud on Securities Markets: Theory and Evidence, 1992 U. ILL. L. REV. 691, 740 \& n.71 (1992).

${ }^{59}$ Mahoney, supra note 43, at 631.

${ }^{60} I d$. at 633-34.

${ }^{61}$ See Marcel Kahan, Securities Laws and the Social Costs of "Inaccurate" Stock Prices, 41 DUKE L.J. 977, 1042 (1992) ("In this Article, I have put forward a comprehensive framework for analyzing the benefits of a wide range of securities laws directed toward enhancing stock price accuracy."). Kahan omits financial manipulation as a possible cause for inaccurate stock prices (but lists non-disclosure, misassessment, speculative trading and liquidity crunches). Id. at 988-94.

${ }^{62}$ Id. at 1034-35. For the wealth effect, many consumers must also be investors. Alternately, non-investors anticipate the wealth effect to investors, precipitating a recession.

${ }^{63}$ Earnings manipulations created a "generally adverse attitude of capital markets towards companies and their executives," leading to poor "growth of business investment and the consequent product loss over the last two to three years." Baruch Lev, Corporate Earnings: Facts and Fiction, 17 J. ECON. PERSP. 27, 43 (2003).

${ }^{64}$ For representative recent papers studying the effect of accounting fraud on financial markets, see e.g., Merle Erickson, Michelle Hanlon \& Edward Maydew, How Much Will Firms Pay for Earnings That Do Not Exist? Evidence of Taxes Paid on Allegedly Fraudulent Earnings, 79 ACCT. REV. 387 (2004); Edward J. Kane, Continuing Dangers of 
proponents of more spirited enforcement, who recognize that "[m]isstatements create several types of harms," include only costs borne by investors among them: higher verification costs, raised liquidity costs for liquidity traders, and higher agency costs for all corporations. ${ }^{65}$

As a result of their myopic focus on investors' losses, commentators have criticized increased regulatory intensity and more vigorous enforcement, including criminal prosecutions and private litigation. ${ }^{66}$ Usually, the critics assert that securities fraud is "overlitigated,"67 that sanctions "overcompensate" 68 investors and "overdeter," "overpay"70 for their employees' misdeeds.

Cost-benefit analyses of corporate governance are inherently difficult because we lack reliable information on the cost and the prevalence of wrongdoing, on the cost of prevention and enforcement, and on the wrongs prevented by regulation. But, if the social cost of financial misrepresentations is greater than is currently assumed, then compliance and enforcement predicated on the assumption of lower cost will produce less accurate disclosures than is socially optimal. ${ }^{71}$

Disinformation in Corporate Accounting Fraud, 13 REV. FIN. ECON. 149 (2004); Karpoff et al., supra note Error! Bookmark not defined. (discussing losses to firms reporting accounting fraud as measured by stock price decline of the firm); Joshua Ronen, Post Enron Reform: Financial Statements Insurance, and GAAP Revisited, 8 STAN. J. L. \& BUS. 39 (2002).

65 Zohar Goshen \& Gideon Parchomovsky, The Essential Role of Securities Regulation, 55 DUKE L.J. 711, 719 (2006). See also Rose, Multienforcer Approach, supra note 39, at 2179-80 (cataloguing the social costs of fraud in the post-Enron world and including investors' verification costs, liquidity costs, and impaired ability to monitor corporate managers).

${ }^{66}$ See sources cited supra note 28.

67 See e.g., Jessica M. Erickson, Overlitigating Corporate Fraud: An Empirical Examination, 97 IOWA L. REV. _ (2011) (forthcoming) (observing that corporate fraud often leads to the filing of parallel lawsuits, which target the same underlying misconduct); Mahoney, supra note 43, at 623-24 (arguing that the fraud-on-the-market doctrine overdeters voluntary disclosure by firms).

${ }^{68}$ Thakor et al., supra note 47, at 1.

69 Amanda M. Rose, Reforming Securities Litigation Reform: Restructuring the Relationship Between Public and Private Enforcement of Rule 10b-5, 108 COLUM. L. REV. 1301, 1303-04 (2008) [hereinafter Rose, Reforming Securities Litigation].

${ }^{70}$ Baer, supra note 20, at 1063; Lisa K. Griffin, Compelled Cooperation and the New Corporate Criminal Procedure, 82 NYU L. REV. 311 (2007).

${ }^{71}$ See e.g., Lynn Bai, James D. Cox \& Randall S. Thomas, Lying and Getting Caught: An Empirical Study on the Effect of Securities Class Action Settlements on Targeted Firms, 158 U. PA. L. REV. 1877, 1883 (2010) (studying the costs of securities class actions); Erickson, supra note 67, at 55 (analyzing the costs of corporate fraud litigation). 


\section{THE BIGGER PICTURE}

This Part details the many ways in which financial misrepresentations distort decisions by firms and the providers of capital and labor. It then summarizes empirical evidence on the cost of false disclosures, both internal to the fraud-firm and external. Cost to non-shareholders may be less visible (at least immediately) and thus harder to quantify than stock price declines, but is no less real. More importantly, non-shareholders are generally less able than investors to insure against or diversify against their risk. The Part concludes with an analysis of the factors that affect the size of the distortion caused by fraud. Not surprisingly, the size of the fraudcommitting firm, both absolute and relative to its industry peers, and the duration of the misrepresentation both increase the harms from fraud. More surprisingly, product market competition affects both the size of the distortion and the distribution of the cost from fraud: the less competitive the product market, the more the affected firms are able to shift the cost away from its investors.

\section{A. Financial Misrepresentations and Market Distortion}

Stock manipulation through stock pools was the motivating factor driving the adoption of the Securities Exchange Act of 1934. Manipulative stock pools consisted of agreements among a group of traders to delegate authority to a single manager to trade in a specific stock for a set period of time and share the profits. ${ }^{72}$ Pool managers bought large quantities of the stock to boost its price, hoping to spark the interest of other buyers, and then sell the stock to them at a profit. ${ }^{73}$ Although there is much disagreement about how much harm stock pools in fact caused, ${ }^{74}$ they were perceived to be "the chief evil for which a remedy [was] demanded.",75

Manipulative stock pools produce two types of false information: a high stock price and inflated trading activity. This distorts investors' behavior,

72 Guolin Jiang, Paul G. Mahoney \& Jianping Mei, Market Manipulation: A Comprehensive Study of Stock Pools, 77 J. FIN. ECON. 147, 148-49 (2005).

${ }^{73}$ Id. Similar stock manipulation techniques have remained popular to this day. SEC Charges Boiler Room Operators in Florida-Based Penny Stock Manipulation Scheme, Jan. 26, 2012, available at http://sec.gov/news/press/2012/2012-18.htm/.

${ }^{74}$ See e.g., Jiang et al., supra note 72 , at 147 (finding that stock pools were used for manipulation, but led to only moderate short-run price increases).

${ }^{75}$ Report to Secretary of Commerce of Committee on Stock Exchange Regulation 13, reprinted in 5 LEGISLATIVE HISTORY OF THE SECURITIES ACT OF 1933 AND SECURITIES EXCHANGE ACT OF 1934 item 16 (J. Ellenberger \& E. Mahar eds. 1973). 
but does not directly influence decisions by other market participants. ${ }^{76}$ Moreover, the wrongdoer manipulates stock prices intending to defraud investors.

Financial misrepresentations, on the other hand, are accompanied by inflated stock prices, but the stock price is only a symptom of the false disclosure. Market participants, including the firm's employees and lenders, its suppliers and rivals rely on specific false disclosures about the firm's business operations, which impairs their ability to make accurate decisions. In addition, managers' motivations for misrepresenting their earnings are more complex than the motivations of stock manipulators: they want to mislead their shareholders, but also the analysts, their rivals, their employees and lenders. Thus, one would expect that financial misrepresentations distort the allocation of economic resources andbecause such distortion affects all firms, not just fraudulent ones-the effects of such distortion are significant.

Equity bubbles, like the tech bubble in the late 1990s, also pull resources from other sectors, move savings into equities, and affect the cost of borrowing. ${ }^{77}$ Like fraud, bubbles might be followed by business failures and layoffs. But they do not distort decisions within an industry and thus do not distort product markets directly.

The most common reason for fraudulent disclosures appears to be subpar performance. ${ }^{78}$ Managers fear dismissal if they report disappointing earnings. In response, they overstate earnings, hoping to make up the

${ }^{76}$ Moreover, stock prices alone convey relatively little information compared with financial disclosures. And so, one would expect that they produce a smaller distortion to markets other than equity.

${ }^{77}$ The internet and telecommunication booms are recent examples. An older example includes railroads: extensive miles of track were laid (including spurs to future towns not yet built) by firms in the railroad industry only to be followed by numerous bankruptcies in the late 1870s. See Illinois Railroad Boom, 1865-73, http://www.eslarp.uiuc.edu/ibex/ archive/vignettes/rrboom.htm. The Chicago Sun Times wrote in 1872 that wealth from the railroads "will so overflow our coffers with gold that our paupers will be millionaires ..." Id.

${ }^{78}$ Arlen \& Carney, supra note 58, at 701. Even in the largest frauds, managers rarely set out to commit the fraud that ultimately results. As Don Langevoort and others have suggested, managers usually begin by manipulating "just a little," perhaps to cover a temporary blip in performance, and hope that they can smooth over the manipulation in the next period. When the next period fails to bring good news, the slippery slope leads managers to ever greater manipulation. See Donald C. Langevoort, Resetting the Corporate Thermostat, Lessons from the Recent Financial Scandals about Self-Deception, Deceiving others and the Design of Internal Controls, 93 GEO. L.J. 285, 308 (2004); Michael Guttentag, Stumbling Into Crime: Stochastic Process Models of Accounting Fraud, in RESEARCH HANDBOOK ON THE ECONOMICS OF CRIMINAL LAW (A. Harel \& K. Hylton, eds. 2011). 
shortfall in the next period and disguise the fraud. ${ }^{79}$ Other managers might misreport their firm's performance because of greed: the structure of managerial compensation provides supercharged incentives for fraud. They overstate the firm's financials to inflate the stock price, exercise their stock options, and pocket millions of dollars. ${ }^{80}$

Whatever the reason for the misrepresentation, all frauds are alike: the firm releases a misleading financial statement, often accompanied by similarly misleading public pronouncements. In addition to making a false disclosure, fraud firms change their real actions to conform to their reported financial health. ${ }^{81}$ Managers might sell output at a loss, announce new projects, overinvest in fixed assets, and overhire. Indeed, there is evidence that managers frequently go to great lengths to conceal fraud. They lie to their accountants, ${ }^{82}$ threaten dismissal to those who resist, ${ }^{83}$ reduce their prices to convey to competitors the appearance of superior performance, ${ }^{84}$ and even pay taxes on nonexistent earnings. ${ }^{85}$

Although financial statements are prepared for shareholders, a much broader array of actors uses them and adjusts their actions based on their reliance. Employees make career and retirement decisions based on perceived prospects of their employer, lenders price credit based on

${ }^{79}$ See id. at 702-03 (identifying the "last period" problem as an important cause of accounting fraud).

${ }^{80}$ See Adam C. Pritchard, Markets as Monitors: A Proposal to Replace Class Actions With Exchanges as Securities Fraud Enforcers, 85 VA. L. REV. 925, 932-34 (1999) (arguing that greed can induce managers to commit accounting fraud).

81 See Gil Sadka, The Economic Consequences of Accounting Fraud in Product Markets: Theory and a Case from the U.S. Telecommunications Industry (WorldCom), 8 AM. L. \& ECON. REV. 439, 447 (2006) (observing that managers will change their business decisions to conceal fraud, but only if fraud itself is punished).

${ }^{82}$ See e.g., BETHANy MCLEAN \& PETER Elkind, THE SMARTEST GuYs in the RoOM: The AMAZING Rise AND SCANDALOUS FALL OF ENRON 128, 157-58 (2003) (describing examples of deals where Enron executives misrepresented facts to its accountants, Arthur Andersen).

83 Sherron Watkins and Cynthia Cooper, accountants at Enron and WorldCom respectively, brought accounting problems to the attention of management. Both were threatened with termination and Watkins was reassigned. See Kathleen F. Brickey, From Enron to WorldCom and Beyond: Life and Crime After Sarbanes-Oxley, 81 WASH. U.L.Q. 357, 362-63, 369 (2003). The Sarbanes-Oxley Act later prohibited retaliation against whistleblowers, and the Dodd-Frank Act further strengthened whistleblower protections by allowing the SEC to give them a cut of the recovery. See discussion infra in Part IV.

${ }^{84}$ See Sadka, supra note 81, at 439, 457-58 (arguing that WorldCom fraud caused price competition and not vice versa).

${ }^{85}$ See Erickson, Hanlon \& Maydew, supra note 64, at 389-90 (reporting that out of 27 firms subject to SEC enforcement actions, 15 paid taxes on overstated earnings; the total amount of taxes paid represented $2.4 \%$ of the firms' market value and $20 \%$ of the pretax value of overstated earnings). 
reported financials, and suppliers set payment terms based on the reported financial health of their counterparty. ${ }^{86}$ Assuming that the supply of labor and capital is not infinite, fraud makes both labor and (debt and equity) capital relatively more costly for non-fraud firms (than for fraud firms) while fraud is ongoing, but before it is unmasked. ${ }^{87}$

Moreover, rivals of fraud firms make business decisions on a distorted playing field. Learning plays an important role in technology development, which is critical to growth; firms learn by observing their rivals' actions. Other firms' financial disclosures and annual reports are "excellent source document[s]" that mitigate uncertainty about industry-level demand and costs, help firms in the same industry make strategic decisions, and distinguish good projects from bad ones. ${ }^{88}$ They are also cheap (certainly cheaper that industrial espionage), comprehensive, and relatively reliable, because they are audited and certified, and carry a non-trivial risk of liability if found to be false. ${ }^{89}$

${ }^{86}$ Firms exist because transaction costs of repeated market transactions exceed the costs of allocating those same resources within the firm. In intra-firm relationships, accurate information is essential for owners of the factors of production-labor, capitalto respond to changed conditions. See Ronald H. Coase, The Nature of the Firm, 4 ECONOMICA 386 (1937).

${ }^{87}$ Oren Bar-Gill \& Lucian A. Bebchuk, Misreporting Corporate Performance 24 (Harv. L. \& Econ. Discussion, Paper No. 400, 2002).

${ }^{88}$ Durnev \& Mangen, supra note 13, at 680-81 (citing from P. Moon \& K. Bates, Core Analysis in Strategic Performance Appraisal, 4 MGMT. ACCT. RES. 139, 140 (1993)); Phillip G. Berger \& Rebecca Hann, Segment Disclosures, Proprietary Costs, and the Market for Corporate Control, at 30 (finding evidence that competitors cannot learn proprietary information about segment profitability unless it is disclosed); Robert $\mathrm{M}$. Bushman \& Abbie J. Smith, Financial Accounting Information and Corporate Governance, 31 J. ACCT. \& ECON. 237, 293-94 (2001). Since 1997, the FASB has required public firms to disclose profit or loss, certain specific revenue and expense items, and assets by each operating segment in which the firm operates. In addition, firms must report in which geographic markets they operate and who are their major customers. See FIN. Acct. Standard Bd., Statement of FinAnCial AcCounting Standards No. 131, at 4-5 (1997). Cf. Phillip G. Berger \& Rebecca Hann, Segment Profitability and the Proprietary and Agency Costs of Disclosure, 82 ACCT. REV. 869, 872 (2007) (finding evidence that, if able to, managers want to hide from their competitors information about the profitability of a particular segment relative to the industry to deter business entry and maintain high abnormal profits). Conversely, reporting false profits would (inefficiently) invite business entry. Id.

89 See Sadka, supra note 81, at 447 (noting that "enforcement makes financial statements credible"); J. Gregory Sidak, The Failure of Good Intentions: The WorldCom Fraud and the Collapse of American Telecommunications After Deregulation, 20 YALE J. ON REG. 207, 209-10 (2003) (arguing that because WorldCom's reporting about the growth of its business was subject to regulatory oversight, "it was reasonable to rival carriers to believe WorldCom's misrepresentation"). 
Significant misreporting, particularly one of "core accounts, such as sales, market share, and cost," 90 impairs rivals' ability to discern the value of new business strategies, and other market participants' ability to understand the markets in which they operate. ${ }^{91}$

In other words, firms' managers do not know ex ante which business strategy is optimal, and so they look to their rivals as gauges of what the market wants. If the market appears to reward particular strategies reported in financial disclosures, rivals will mimic what they perceive to be the best performer. If that performer is not in fact the best, an entire industry might adopt a misguided business strategy (and overinvest, overborrow and overhire) while fraud is ongoing. ${ }^{92}$

Correcting a false disclosure causes providers of capital and labor to adjust their risk-assessment of the fraud firm. Business failure is common in the aftermath, and employees, lenders, and those doing business with the fraud firm are often harmed. Assuming that fraud is an idiosyncratic event, rivals should, in theory, benefit, not lose, from its unmasking. A significant restatement is costly for the firm, and so its rivals could use that opportunity to grab that firm's market share. Thus, one would expect that rivals could attract capital and labor at lower rates than before fraud was unmasked. ${ }^{93}$ (However, suppliers, distributors, and others doing business with the fraud firm are expected to incur losses after fraud is unmasked.)

On the other hand, providers of capital (and, to a much lesser extent, labor) do not know if rivals of the fraud firm are misreporting also, so they demand higher risk premia or sell their stock in rival firms, which depresses their stock prices. In accounting literature, the negative effect of discovery of accounting fraud in one firm on equity prices of rival firms is called contagion. Studies attribute the contagion effect to two factors: investor

\footnotetext{
${ }^{90}$ Durnev \& Mangen, supra note 13, at 681.

91 Abigail Brown \& Simon D. Angus, Destroying Creative Destruction: The Social Welfare Cost of Fraud, at 4. See generally Richard R. Nelson \& Sidney G. Winter, Evolutionary Theorizing in Economics, J. ECON. PERSP., Spring 2002, at 23 (explaining evolutionary economics and comparing its with neoclassical assumptions).

${ }^{92}$ See Brown \& Angus, supra note 91, at 4-5 (describing the process of learning and economic growth).

93 See Tan Xu, Mohammad Najand \& Douglass Ziegenfuss, Intra-Industry Effects of Earnings Restatements, 33 J. BUS. FIN. \& ACCT. 696, 697 (2006) (noting that an "earnings restatement could have competitive effect because it could decrease the restating firm's competitiveness relative to its competitors"). See also Larry H.P. Lang \& Rene M. Stultz, Contagion and Competitive Intra-Industry Effects of Bankruptcy Announcements: An Empirical Study, 32 J. FIN. ECON. 45 (1992) (finding that bankruptcies in concentrated industries tend to be positively correlated with rivals' stock prices).
} 
concerns about accounting quality, and higher cost of capital as a result of concerns about accounting quality (i.e., higher risk). ${ }^{94}$

In addition to contagion, unmasking of fraud discloses that the prospects of a particular industry are less rosy than previously believed. In response, firms in that industry reevaluate their expected return from existing investment and reduce current investment, reducing their demand for labor and capital. Lower expected returns are reflected in lower equity prices.

One might contend that firms disclose their financial information to investors and thus other market participants have no right to rely on them: their reliance is not justifiable in a legal sense. That may be, but information is a public good. Once the cat is out of the bag, it is impossible to exclude market participants from using and relying on disclosed information. Moreover, it is social welfare enhancing for market participants to rely on accurate disclosures and make better-informed investment decisions. ${ }^{95}$ Conversely, their reliance on fraudulent financial disclosures reduces social welfare. $^{96}$ Even if the disclosing firm's stakeholders ${ }^{97}$ and its rivals have no legal right to sue for financial misrepresentations, the harms they suffer ought to be included in the calculation of the total harm that the misrepresentation causes.

\section{B. Empirical Evidence on the Cost of Financial Misrepresentations}

The following sections review the empirical literature estimating the cost of financial misrepresentations on markets for capital, labor, and product markets. Distortions impose direct costs, as firms misinvest during fraud, and indirect costs, as contagion causes investors to flee capital markets and firms to shrink their businesses. Some of the costs of fraud are internal to the fraud firm (i.e., bankruptcy), while others are external (i.e.,

94 See Xu et al. supra note 93, at 698 (explaining the causes and mechanics of the contagion effect).

${ }^{95}$ Recent studies suggest that high-quality financial disclosures provide better direction for all managers' business decisions. See Jeffrey Wurgler, Financial Markets and the Allocation of Capital, 58 J. FIN. ECON. 187, 207, 209 (2000) (finding evidence that betterinformed stock prices help managers and investors direct resources to growing industries); Bushman \& Smith, supra note 88, at 304-05 (explaining that financial disclosures limit opportunities for managerial rent-seeking). See also George J. Benston, Required Disclosure and the Stock Market: An Evaluation of the Securities Exchange Act of 1934, 63 AM. ECON. REV. 132, 144 (1973) (noting that information that the firm is required to disclose is valuable to competitors and thus disclosure is costly to the firm and its investors).

${ }^{96}$ Sadka, supra note 81, at 458; Bower \& Gilson, supra note 26, at 21.

97 The Article uses the term "stakeholders" to include all non-shareholders with an interest in the enterprise: employees, creditors, customers, suppliers, distributors, etc. 
product market distortion). The Part first discusses intra-firm costs to shareholders and non-shareholders. It then broadens the scope to external costs to markets for equity, debt, labor, and product markets.

\section{Intra-firm Cost}

\section{a. Cost to Shareholders in the Fraud Firm}

Many scholars assume that fraud is zero-sum for a firm's shareholders. Sellers win, buyers lose, and those who hold on are unaffected by fraud. ${ }^{98}$ For this to be true, one must assume that fraudulent disclosures inflate stock prices, while eventual exposure of fraud returns the price to the correct level (reflecting fundamentals), which is what the price would have been absent fraud. ${ }^{99}$ Subsequent investigation and sanctions impose real cost on firms and thus their shareholders, but that is an argument for abandoning all enforcement. ${ }^{100}$ Because investors can diversify, they are "effectively protected against securities fraud."101 Thus, enforcement is at best a costly distraction and at worse a drag on our economy.

While this story could be true for a Basic fraud, where managers publicly denied (untruthfully) that they were negotiating a merger, ${ }^{102}$ it is not true for accounting fraud. Unmasking accounting fraud does more than just correct the stock price: it discloses accurate earnings, which convey new information about the firm and the prospects of its industry; it discloses that capital and labor were misdirected; and it reports that the firm is a den of thieves. ${ }^{103}$

${ }^{9}$ Alicia J. Davis, Are Investors' Gains and Losses from Securities Fraud Equal Over Time? Theory and Evidence, at 31-32, U. Mich L. Sch., Empirical Legal Stud. Ctr., Working Paper 09-002 (Revised 10/10) [hereinafter Davis, Investors' Gains and Losses] (noting such views and citing authors).

${ }^{99}$ See e.g., Easterbrook \& Fischel, supra note 52, at 635; Thakor et al., supra note 47, at 4 (suggesting that investors who held stock in the fraudulent firm during the fraud period were "undamaged" by the fraud).

${ }^{100}$ Karpoff et al., supra note Error! Bookmark not defined., at 606 (finding that expected damages and fines represent $8.8 \%$ of the stock price decline after discovery of fraud).

${ }^{101}$ Richard A. Booth, Who Should Recover What for Securities Fraud?, at 6.

102 Basic v. Levinson, 485 U.S. 224 (1988).

103 Cf. JAMES B. STEWART, DEN OF THIEVES (1992) (a Pulitzer prize-winning account of fraud and insider trading during the leveraged buyout craze of the 1980s). Although managers can be and usually are replaced after fraud, the culture that created the incentives and the opportunity for fraud is harder to change. See Tom Baker \& Sean J. Griffith, Predicting Corporate Governance Risk: Evidence from the Directors' \& Officers' Liability Insurance Market, 74 U. CHI. L. REV. 487, 519-20 (observing that firm culture-the 
Karpoff, Martin, and Lee demonstrate empirically that financial misrepresentations are more than a net transfer of wealth from one group of shareholders to another. ${ }^{104}$ From a large sample of firms subject to SEC or DOJ enforcement actions, they find that markets punish fraud firms (and their shareholders) severely. They find that for every dollar in increased market value due to fraud, the firm loses that dollar after disclosure of fraud, and an additional \$3.08 (\$3.83 for firms that do not file for bankruptcy). Of that additional loss, only 36 cents (or $8.8 \%$ ) is due to expected legal penalties, while $\$ 2.71$ is lost "reputation," caused by expected lower sales and higher cost of contracting and financing. ${ }^{105}$

A part of the reputational loss represents a transfer of market share from the fraud firm to its rivals, as customers and employees shift, and is not a social cost per se. ${ }^{106}$ But the majority of the reputational losses borne by the fraud firm represent deadweight economic losses: higher costs of contracting and financing reflect increased risk. ${ }^{107}$

As a result, shareholders in the fraud firm who did not trade during the fraud are not indifferent to accounting fraud. They are worse off than they would be absent fraud, and often much worse off, even if the firm never pays damages or fines. ${ }^{108}$ Even if fraud-tainted sales offset fraud-tainted purchases ex post, shareholders would prefer that fewer firms commit fraud ex ante.

\section{b. Cost to Non-Shareholders}

system of incentives within the firm — not just managers' character increases the propensity for fraud, and that culture is difficult to change).

${ }^{104}$ Karpoff et al., supra note Error! Bookmark not defined., at 581.

${ }^{105} \mathrm{Id}$.

${ }^{106}$ A shift that produces zero social cost assumes perfect competition, information, and substitutes, as well as zero transaction costs. When the assumptions are relaxed, as they must be, all transfers will produce social deadweight losses.

107 See Jennifer Arlen, Corporate Criminal Liability: Theory and Evidence, at 8, in RESEARCH HANDBOOK ON CRIMINAL LAW (Keith Hylton \& Alon Harel, eds., forthcoming) (reporting evidence that markets impose reputational penalties on fraud firms even in the absence of a criminal investigation). But see Baer, supra note 20, at 1062-63 (contending that "[c]orporate indictments also trigger reputation losses, including downturns in the stock market, a reduction in potential employees and customers, and the exodus of current customers and employees").

${ }^{108}$ See Arlen, supra note 107, at 8 (reporting that a firm's market value declines by more than the net present value of fines, damages, and other enforcement costs on announcement of a fraud investigation, but not on announcement of an environmental violation). 
About a third of firms that have misreported their financials-often indicated by the fact that the SEC initiated an enforcement action ${ }^{109}$ - file for bankruptcy. ${ }^{110}$ Because many firms that cooked their books were financially stressed beforehand, some number would have filed for bankruptcy anyway. ${ }^{111}$ But, many would not have filed. Also, a substantial percentage of firms were financially healthy before the fraud. ${ }^{112}$

Accounting fraud in a firm that would have filed for bankruptcy regardless is not costless. Fraud harms those who extended unsecured credit, as well as those who bought shares after the fraud began. But, there are other costs to delaying the inevitable by fraud. Accounting fraud is more than misstated financials, since managers mask the fraud, both by issuing misleading public announcements and by changing the firm's business decisions to mask the fraud. Stakeholders rely on both and act differently than if the true (bleak) picture were known. Moreover, fraud often precipitates a sudden bankruptcy, and the very swiftness is costly by itself. ${ }^{113}$ Because fraud obscures accurate signals from the stakeholders,

109 See e.g., COMMITTEE OF SPONSORING ORganizations OF THE TREADWAY Commission, MARK BeAsley AT AL., FraudulEnt FinANCIAL REPORTING 1998-2007: AN ANALYSIS OF U.S. PUBLIC COMPANIES 1 (2010) ("We analyzed instances of fraudulent financial reporting alleged by the SEC in AAERs issued during the ten-year period between January 1998 and December 2007.") [hereinafter COSO STUDY]; DELOITTE FORENSIC CENTER, TEN THINGS ABOUT BANKRUTPCY AND FRAUD: A REVIEW OF BANKRUPTCY FILINGS 1 (2008) (noting that the authors reviewed AAERs issued during the study period), available at http://www.bankruptcyfraud.typepad.com/Deloitte Report.pdf/; Karpoff et al., supra note Error! Bookmark not defined., at 586-87 (2008) ("Enforcement actions commonly include a mixture of proceedings that may implicate the firm itself, other affiliated firms, or individuals associated with the firm. The SEC publicly discloses these proceedings by filing administrative or litigation releases.").

${ }^{110}$ See COSO STUDY, supra note 109 , at $40 \&$ Tbl. 28 (reporting that $28 \%$ of the firms subject to an AAER between 1998 and 2007 filed for bankruptcy within two years thereafter); Karpoff et al., supra note Error! Bookmark not defined., at 593 (reporting that $34 \%$ of firms subject to an SEC or Department of Justice enforcement action between 1978 and 2002 filed for bankruptcy).

${ }^{111}$ See COSO STUDY, supra note 109, at 11 (reporting that the median net income of a fraudulent firm was $\$ 875,000$, while the $25^{\text {th }}$ percentile firms faced net losses of $\$ 2.1$ million).

${ }^{112}$ See id. (reporting that the $75^{\text {th }}$ percentile firm reported net income of over $\$ 18$ million, while the highest net income firm in the sample reported almost $\$ 8.9$ billion). The study did not disaggregate financial figures for the firms filing for bankruptcy. The Deloitte Study, however, suggests that many bankrupt firms that committed fraud (measured by an issuance of an AAER) had very high revenues: $45 \%$ of firms reported revenues of more than $\$ 1$ billion and $10 \%$ reported more than $\$ 10$ billion. DELOITTE FORENSIC CENTER, supra note 109 , at 9 .

113 Financial misrepresentations undermine "the firm's credibility with customers, suppliers, and investors," which is essential for its continued viability. Filing for 
they may face longer periods of dislocation and higher opportunity costs that they could have avoided if they had known the truth about the firm (e.g., employees could have looked for new jobs earlier had they seen the true writing on the wall).

The cost of fraud in an otherwise viable firm is even clearer: in bankruptcy, shareholders are wiped out, employees lose their jobs, suppliers and vendors lose their client, and creditors lose at least part of their claim, not to mention the community disruption resulting from the loss of a major business. ${ }^{114}$ Not all fraud-induced bankruptcies result in liquidation. Rather, the business reorganizes, mitigating the harm of bankruptcy to the stakeholders (as well as the shareholders, who often receive an equity slice in the reorganized firm). ${ }^{115}$ But, bankruptcy itself is a costly process and usually produces a smaller firm than one that entered it.

Even those fraud firms that avoid bankruptcy often suffer other significant consequences: they frequently delist (47\% compared with $20 \%$ for non-fraud firms over a 10-year period) and are twice as likely as their honest peers to engage in material asset sales (63\% vs. $31 \%) .{ }^{116}$ As with bankruptcy, delisting and material asset sales impose real costs not only on shareholders, but also on the companies' stakeholders. Substantial business shocks like fraud are often accompanied by a retrenchment including a reduction in sales, investments, and employment.

\section{External Costs}

Fraud infects equity markets and distorts equity investment. But, fraud also distorts the allocation of other inputs, including debt and labor, and

bankruptcy might be the only option remaining. Karpoff et al., supra note Error! Bookmark not defined., at 601.

${ }_{114}$ See James J. Park, Assessing the Materiality of Financial Misstatements, 34 J. CORP. L. 513, 553-54 (2009) (noting that accounting fraud can lead to insolvency, which harms not only the shareholders, but also other stakeholders, such as employees and communities).

115 See UCLA-LoPucki Bankruptcy Research Database, http://lopucki.law.ucla.edu/ study_results.asp/ (suggesting that most fraud-induced bankruptcies resulted with a confirmed Chapter 11 plan of reorganization). The presence of a confirmed Chapter 11 plan, however, overstates the number of fraud firms that survived bankruptcy. Enron emerged with a confirmed Chapter 11 plan, but the sole purpose of the surviving entity, Enron Creditors Recovery Corp., is to liquidate Enron's assets for the benefit of its creditors. See Enron Creditors Recovery Corp., About ECRC, $\mathrm{http}: / / \mathrm{www} \cdot$ enron.com/index.php?option $=\mathrm{com}_{-} \quad$ content\&task=view\&id=1\&Itemid=9/ (last visited Oct. 4, 2011).

${ }^{116}$ COSO STUDY, supra note 109 , at 40. 
product markets. This Part explains the mechanism and estimates the cost of the distortion.

\section{a. Equity Market Effects}

It is commonly believed that any actively-trading individual investor can eliminate the risk of loss from secondary market fraud by diversifying her holdings. ${ }^{117}$ But, while diversification eliminates investors' exposure to firm-specific risk of fraud (by spreading the risk over many investments), it does not eliminate the cost of fraud in the market. If a single fraud produces a loss of $\kappa$, ten frauds usually produce equity losses of more than $10 \kappa$. The cost is greater because ten frauds signal that managers generally cannot be trusted (i.e., contagion). In the early 2000s, when financial restatements became nearly everyday occurrences, equity markets suffered severely. ${ }^{118}$

The argument that diversified investors are indifferent to accounting fraud thus assumes that the level of fraud will remain the same over time. ${ }^{119}$ If, however, the level of accounting fraud increases, the perceived riskiness of investing in equity will, likewise, increase and-ceteris paribus-reduce expected returns on equity investments. That systemic risk cannot be diversified away because it will infect all public firms, affecting both equity and debt. ${ }^{120}$

Unlike investors, firms cannot easily reduce the risk of capital misallocation because of fraud. The supply of capital is not infinite; capital consumed by the fraud firm could have gone to a worthier firm, which creates a significant opportunity cost while fraud is ongoing. Enron, for

117 Davis, Investors' Gains and Losses, supra note 98, at 1-2 (citing several sources supporting the view, but then finding that they are wrong).

${ }^{118}$ As a matter of comparison, when the tech bubble in the spring of 2001, the Dow Jones Industrial Index ("DJIA") declined almost 20 percent from its peak in the winter of 2000. During accounting scandals, between May 2001 and the fall of 2002, the DJIA lost almost 36 percent.

119 Investors "are indifferent between investing at a lower price in a firm with an inefficient institutional arrangement and investing at a higher price in a firm where they are better protected." Daniel R. Fischel, Labor Markets and Labor Law Compared With Capital Markets and Corporate Law, 51 U. CHI. L. REV. 1061, 1063 (1984). But society as a whole will suffer because fewer goods and services will be produced. Id.

${ }^{120}$ See e.g., Coates, supra note 29, at 92-96 (reporting that systemic fraud before Sarbanes-Oxley increased costs for all firms, whether or not they engaged in fraud). The systemic risk discount can be very large. Russian manufacturing companies privatized at a 99-percent discount, and Russian oil companies, similarly, were valued at a 99-percent discount compared to Western firms. Some of the discount reflects the likelihood of government expropriation, but some reflects the ability of Russian managers to divert profits and assets to themselves. See Andrei Shleifer \& Robert W. Vishny, A Survey of Corporate Governance, 52 J. FIN. 737, 748 (1997). 
example, was a gluttonous consumer of financial (and human) capital, amassing more than $\$ 60$ billion of equity capital. Without fraud, that capital would have gone elsewhere.

After fraud is unmasked, the effect on firms in the same industry is more pronounced than the effect on equity markets generally. There is evidence that a restatement, even one unaccompanied by an enforcement action, has a statistically significant negative impact on the stock price of all firms in the industry, not just the restating firm.

Gleason, Jenkins and Johnson's study is a good example for the afterthe-fact effects of a (mere) restatement on stock-prices of non-restating firms in the same industry. ${ }^{121}$ Gleason and her collaborators find that stockprices of rivals decline because of investors' concerns with accounting quality in that industry more generally. Not surprisingly, the authors find that the effect is more pronounced when the restating firm is relatively large and when restating and non-restating firms use the same external auditor. ${ }^{122}$ They also find that firms with high accruals - sales recorded before cash is received, also known as accounts receivable-suffer greater losses than those with relatively low accruals. ${ }^{123}$

Contagion is only one of several competing explanations for why rivals' stock prices suffer declines after a restatement in the industry. Durnev and Mangen observe that investment in the industry is depressed for a number of years after a restatement. They argue that a restatement releases new information about the prospects of the industry, which causes rivals' to reevaluate (and reduce) their own investment. ${ }^{124}$

By testing their hypotheses that rivals rely on their peers' financial statements and that restatements convey new information, Durnev and Mangen find that rivals significantly reduce their investments within three years after the restatement. ${ }^{125}$ A lower level of investment is not (solely) the product of changed opportunities for external financing, investor concerns about accounting quality, or subsequently higher cost of debt funding, as

${ }^{121}$ Christi A. Gleason, Nicole Thorne Jenkins \& W. Bruce Johnson, The Contagion Effects of Accounting Restatements, 83 ACCT. REV. 83 (2008).

${ }^{122} \mathrm{Id}$. at 84 .

${ }^{123} I d$. at 83 . Accruals more accurately reflect the business prospects of a firm, but they are less reliable than measuring sales by cash flow because management can exercise more discretion in accounting for accruals.

${ }^{124}$ Durnev \& Mangen, supra note 13, at 680-81 (2009).

${ }^{125} \mathrm{Id}$. at 697 (finding that competitors on average reduce investments by $5.6 \%$ in the year of the restatement, by $5.2 \%$ the following year, by $2.6 \%$ the year thereafter and by $16.2 \%$ in the third year after the restatement in the industry). 
other studies would suggest. ${ }^{126}$ Rather, rivals reevaluate their expected return from existing investments and reduce current investment in response.

Durnev and Mangen also confirm one aspect of other studies: restatements have a greater impact on rivals' investments when restating firms have a larger market share. ${ }^{127}$ Both restating firms and their rivals experience significant negative abnormal returns around the announcement date $-8.28 \%$ and $0.34 \%$ respectively. But the aggregate loss to rivals (and their shareholders) is much greater than the harm to shareholders in the restating firm: \$581 million compared with \$141 million. ${ }^{128}$

Goldman, Stefanescu, and Peyer confirm that fraud depresses stock prices of rival firms. ${ }^{129}$ Looking only at restatements accompanied by an SEC enforcement action, the authors find that rivals' stock price on average drops $2.34 \%$ around the date that fraud is unmasked. ${ }^{130}$ Declines are more pronounced in competitive industries, while in the most concentrated industries rivals' stock prices on average increase after discovery of fraud. The authors argue that rivals in competitive industries are less able to capture the fraud firm's market share, both because there are many similarly situated firms vying for customers and because firms in competitive industries are resource-constrained. ${ }^{131}$ In contrast, rivals in concentrated industries can use their (product) market power to pass along the costs of the shock to their customers (protecting their profits and their stock price), while rivals in competitive industries cannot do so. ${ }^{132}$ Ultimately, aggregate equity market losses from fraud to rival firms outstrip the losses to shareholders of fraud firms by nearly an order of magnitude. ${ }^{133}$

\section{b. Debt Market Cost}

In addition to contagion and investment reconsideration, accounting fraud increases the cost of debt for fraud firms and their rivals both before and after fraud is unmasked.

${ }^{126} I d$. at 703 .

${ }^{127}$ Id. at 706 .

${ }^{128} I d$. at 699 . The authors did not disaggregate how much of that loss is the result of shareholders' concerns about the firms' accounting and how much of the expected changes in investment strategy.

${ }^{129}$ Eitan Goldman, Irina Stefanescu \& Urs Peyer, Financial Misrepresentation and Its Impact on Rivals, http://ssrn.com/abstract=774364/.

${ }^{130}$ Id. at 4.

${ }^{131} \mathrm{Id}$

132 Joel Peress, Product Market Competition, Insider Trading, and Stock Market Efficiency, 65 J. FIN. 1 (2010).

${ }^{133}$ Goldman et al., supra note 129 , at 27 \& fig. 3. 
No empirical studies to date have estimated the debt-market distortion during fraud. Assuming that the supply of capital is limited, fraud distorts the allocation of debt between firms. As fraud firms appear healthier than they really are, they can negotiate better borrowing terms than justified. Conversely, non-fraud firms face relatively worse borrowing terms than they would absent fraud. ${ }^{134}$ In a competitive market, higher costs of capital translate into lower levels of investment by honest firms, likely depressing their employment and their market share. Because fraud firms are riskier than they appear, the net cost of misallocated debt capital (and labor, see next section) is positive.

Files and Gurun study the ex post effect of fraud on the cost of debt for restating firms and their rivals, suppliers, and customers. They reviewed the loan terms of firms that borrowed within a year of a rivals' restatement and find that lenders increased loan costs by five to nine basis points. ${ }^{135}$ They find similar effects when looking at loans to firms whose major suppliers or customers restated their earnings. ${ }^{136}$ In addition to demanding a higher interest rate, the lender was more likely to ask for collateral and impose more restrictive financial covenants. ${ }^{137}$

The authors demonstrate that lenders overreact to misreporting within the industry and along the supply chain: lenders tighten lending standards on firms regardless of the firms' accounting quality or overall economic health. ${ }^{138}$ The authors argue that higher cost of borrowing is caused by contagion, ${ }^{139}$ but additional explanations are possible. First, fraud often leads to bankruptcy and only partial loan repayment. Banks face reserve requirements, and a default reduces their ability to extend new credit. Assuming that the supply of capital is not unlimited, the price of credit will increase after fraud even in the absence of contagion. Second, fraud reveals that the prospects of the industry are less rosy than previously believed, and thus rivals' and suppliers' risk profile worse, even if they never engaged in accounting improprieties themselves.

Files and Gurun report that lenders impose relatively stricter postrestatement loan terms in competitive industries than in concentrated industries (measured by firms' relative market shares). ${ }^{140}$ The authors

${ }^{134}$ Bar-Gill \& Bebchuk, supra note 87, at 24.

135 Rebecca Files \& Umit G. Gurun, Lenders' Response to Restatements Along the Supply Chain 20 (July 2011 version), http://ssrn.com/abstract=1636862/.

${ }^{136}$ See id. at 32 (reporting an increase in the interest rate spread by at least seven basis points).

${ }^{137}$ Id. at 27-28.

${ }^{138} I d$. at 29.

${ }^{139}$ Id. at 21-22.

${ }^{140}$ Id. 
attribute it to two factors: the fact that it is more difficult for firms in competitive industries to capture the restating firm's market share, and contagion - the perception that firms in competitive industries are more likely to mimic accounting practices of their peers. ${ }^{141}$ But there is another possible explanation: firms in concentrated industries are able to pass the cost of business shocks, like fraud, onto employees, suppliers, and customers, and thus protect their profits. ${ }^{142}$ Knowing that, lenders demand a lower risk premium.

\section{c. Labor Market Cost}

Financial misrepresentations distort the economic decisions that firms and their employees make, and these decisions invariably affect labor markets. To understand why labor markets might suffer, consider the following. People respond to new information: financial misrepresentations, accompanying reassuring statements, and firm behavior consistent with reported financials induce both workers and rivals (as employers) to adjust their actions to the reported reality. ${ }^{143}$

Employees who know a firm is tottering will look for new work long before the end comes. Fraud upends employees' ability to leave or demand additional pay for the additional risk assumed, because fraud credibly conveys to employees that the firm is doing better than it really is. ${ }^{144}$ Dishonest managers are aware of the risk of flight and try to reassure their workers, just as they reassure providers of capital: they sell the lie to mask fraud and to prevent employee exodus. ${ }^{145}$

${ }^{141}$ Id. at 21 .

${ }^{142}$ See discussion infra in Part II.C.2.c.

${ }^{143}$ Cf. Kent Greenfield, The Unjustified Absence of Federal Fraud Protection in the Labor Market, 107 YALE L. J. 715, 719 (1997) [hereinafter Greenfield, Labor Fraud] (noting that employees rely on company representations about the firms' prospects, improve their productivity and make important personal decisions such as buying a house, and that companies seek such reliance).

${ }^{144}$ See id. at 739-40 (explaining the relationship between job security and pay). Of course, employees complicit in the scheme will not rely on the false financial picture of the firm.

145 See Faith K. Stevelman, Bombing Markets, Subverting the Rule of Law: Enron, Financial Fraud, and September 11, 2001, 76 TUL. L. REV. 1579, 1596 (2002) ("Lay reassured employees about the positive financial prospects of the firm and even suggested that they would benefit from purchasing more Enron stock."). See also Greenfield, Labor Fraud, supra note 143, at 718-19, 721 \& n.26 (recounting numerous stories of employer fraud, usually featuring managers who reassured workers that the firm was profitable to prevent flight, even though they planned to shut down the factory). 
Finding work is costly and time-consuming, certainly as compared with the ability of investors to find alternative investments. ${ }^{146}$ When fraud is unmasked, firms unravel quickly (certainly more quickly than most business failure), exposing employees to unemployment. If they knew the truth about the firm, employees could have looked for work sooner. In addition, as their current job becomes less desirable in the eyes of potential new employers, the workers become less desirable candidates for hire, which further diminishes the odds of finding employment on equal terms. Employees often make firm-specific investments that cannot be transferred easily to another job and will be lost. ${ }^{147}$ Finally, when firms shed many employees simultaneously, that extra supply will depress wages, at least locally.

Fraud also distorts the allocation of labor between firms: it increases the relative cost of labor for non-fraud firms, just as it increases their cost of capital. ${ }^{148}$ The deadweight losses in labor markets caused by accounting fraud should be greater than those in financial markets. Fraud in the secondary market for securities misallocates shares among traders, but does not misallocate equity financing between firms. In contrast, the market for labor is a primary market. Fraud misallocates labor from a "higher-value use to a lower-value use [and thus] inflicts a deadweight loss on society in every case." $" 149$

Finally, debt and equity investors can self-insure ex ante against accounting fraud by lending to or investing in many different firms. While diversification increases the odds that at least one of their investments will be affected by fraud, it reduces the loss to their portfolio. Workers cannot diversify their human capital. Accounting fraud by their employer affects their entire human capital. For most, human capital constitutes a large percentage of their wealth, so the loss will be substantial, even if the displacement is only temporary. ${ }^{150}$ The loss is exacerbated if employees also expect a company pension or invest in company stock.

Kedia and Philippon estimate the real economic costs of financial misstatements to labor markets by examining a large sample of restating

${ }^{146}$ See Greenfield, Labor Fraud, supra note 143, at 749 (noting that the "exit option" for workers is much more costly than it is for capital).

147 See Margaret M. Blair, Firm-Specific Human Capital and Theory of the Firm, in EMPlOYEeS AND CORPORATE GOVERnANCE (Margaret M. Blair \& Mark J. Roe, eds., 1999).

${ }^{148}$ See Greenfield, Labor Fraud, supra note 143, at 743 (noting that "the cost of labor for the economy as a whole would rise because workers would have to be compensated for being subject to fraud by their employers").

${ }^{149}$ Id. at 749.

${ }^{150}$ Fischel, supra note 119 , at 1068. 
firms between January 1997 and June 2002, when about ten percent of all listed firms restated their earnings at least once. ${ }^{151}$ They find that restating firms hire and invest more than comparable firms during periods of suspicious accounting, and reduce labor and borrowing, and sell capital assets after the restatement. ${ }^{152}$ To maintain consistency between reported numbers and their business operations, restating firms mimic firms that are growing as fast as the numbers would suggest. ${ }^{153}$ The authors show that overinvestment would not have been possible but for the financial misrepresentation. $^{154}$

The implications of the Kedia and Philippon study are significant. Restating firms overhire and overinvest during the period of the misrepresentation and reduce both labor and capital thereafter. The subsequent decline is not offset by the earlier growth-it exceeds it and exceeds substantially the trends in the economy. While all non-farm payrolls increased by $6.7 \%$ between 1997 and 1999 and then declined by $1.5 \%$ in 2000 to 2002 , employment in studied firms increased by 500,000 $(25 \%)$ and then fell by $600,000 .^{155}$

More troubling is that industries marred by restatements lost jobs permanently, even where rivals were able to reclaim the restating firms' market share. Instead of expanding their employment and investment to compensate for the losses of restating firms, rivals, too, report negative employment and investment growth, coupled with strong labor productivity

151 See Kedia \& Philippon, supra note 51, at 2172 (noting that theirs is the first article to study the "effect of earnings management on the allocation of resources"); GAO. 2002. Financial Statement Restatements. General Accounting Office, Report to the U.S. Senate. A restatement does not always signal fraud, but when 10 percent of firms restate their earnings over a 5-year period and there is no significant change in reporting rules, chances are high that a number of those restatements are frauds.

${ }^{152}$ Kedia \& Philippon, supra note 51, at 2171, 2183, 2184 \& Tbl. 3 (finding that employment growth during the period of fraudulent reporting is $4.1 \%$ higher than in comparable non-fraud firms, and 4.4.\% lower in post-restatement periods; similarly with investments $-4.4 \%$ higher during fraud and $5.6 \%$ lower thereafter).

${ }^{153} I d$. at 2185-87 (showing that "the magnitude of the earnings management and the degree of distortions in employment and investment are related, and that it is unlikely that a similar dynamic of employment and investment could happen without earnings manipulation").

${ }^{154}$ Id. at 2171.

${ }^{155} I d$. at 2193, 2194 \& Fig. 3. 
growth compared with non-restating firms in more honest industries. ${ }^{156}$ However, increased labor productivity was not offset by higher wages. ${ }^{157}$

This picture would not be complete without acknowledging that the effects of fraud vary depending on the demand for labor in a particular market. Enron's employees had a rough time after the firm revealed its accounting improprieties. Employees had firm-specific skills. When the firm disappeared, so did some of the markets it created (wholesale energy and transmission trading), and with them, the demand for labor.

Arthur Andersen, Enron's auditor, imploded very quickly after it was indicted for destroying evidence of fraud. Yet the harm to the Arthur Andersen's auditors from the implosion was relatively minor. Their skills were easily transferrable and their firm-specific investment small. Moreover, the accounting industry boomed after the scandals and demand for auditors soared. While a number of Andersen audit partners retired in the aftermath of scandal, other auditors were gobbled up by the remaining Big Four accounting firms. ${ }^{158}$ Most equity partners were made whole as they changed firms and lower echelons usually retained their seniority, but not in every case. ${ }^{159}$

\section{d. Cost to Product Markets}

Accounting fraud misallocates capital and labor between firms, but also distorts product markets. Fraud firms overinvest in fixed assets and adopt inefficient pricing to mask the fraud, to which their rivals respond. Unless the fraud firm operates a monopoly without complements or substitutes, its pricing or quantity decisions-distorted to correspond with fraudulent financial reporting - will affect product markets. ${ }^{160}$

Using WorldCom fraud as a case study, Sadka finds support for this hypothesis. While it was misreporting its financials, WorldCom charged low prices, increasing its market share. ${ }^{161}$ Its competitors, Sprint and AT\&T, responded by cutting their prices, and saw a substantial decline in

${ }^{156}$ In other words, non-restating firms increase their sales per employee (i.e., claim some of the restating firms' market share), but do not hire any new employees. See id. at 2195, 2197. This could mean that workers become better at their jobs but it can also mean that they are working harder.

157 See discussion supra, in Part II.B.b. [Cite.]

${ }^{158}$ Interview with a senior auditor with one of the Big Four accounting firms (on file with author). Demand for legal and consulting services, likewise, increased.

${ }^{159} \mathrm{Id}$.

${ }^{160}$ Sadka, supra note 81 , at 441.

${ }^{161}$ Id. at 455-56. 
their operating margins. ${ }^{162}$ Bower and Gilson estimate that if WorldCom had set prices according to its real earnings, the industry could have generated an additional $\$ 40$ billion in profit. ${ }^{163}$ Consumers might benefit from product market distortions in the short-term. But if fraud bankrupts an entire industry, consumers are harmed in the long run, especially if the goods are durable. ${ }^{164}$

Alternately, fraud might "work" and allow the firm to cement a dominant position in the industry. Waste Management, a company that "fostered a culture of fraudulent accounting," was charged with fraud not once, but twice. ${ }^{165}$ Yet it survived relatively unscathed and today dominates the market for solid waste removal, often charging monopolistic prices for its services - great for its shareholders, less so for consumers.

Dechow and her collaborators confirm empirically that fraud firms generally increase their scale during fraud. ${ }^{166}$ But, the size of the increase depends on the competitiveness of the industry. Fraud substantially distorts non-competitive product markets and produces billions of dollars in deadweight losses, as World-Com and its impact on the telecommunications industry demonstrate. ${ }^{167}$ In truly competitive markets where price is set by marginal cost, managers cannot easily expand their firm's market share either by lowering prices or increasing sales. If they do, they will quickly bankrupt the firm and fraud will be exposed. Fraud in competitive industries might also be easier to detect, in particular if financial statements of rivals are highly comparable. ${ }^{168}$ Product market competition thus affects the size of the distortion from fraud, but not its existence: one firm's change in price or output will always shift the equilibrium and affect the prices or output of other firms' products. ${ }^{169}$

But, even truly competitive markets do not police fraud effectively all the time. First, investment booms dampen the constraints that managers in competitive industries usually face. Easy money causes firms in competitive

${ }^{162}$ Id. at 457.

${ }^{163}$ Bower \& Gilson, supra note 26, at 20.

${ }^{164}$ Sadka, supra note 81, at 442 \& n.4. For example, when American carmakers were near bankruptcy during the 2008-09 financial crisis, consumers were vary of buying their cars for fear they could not be serviced. To allay their concerns, the federal government guaranteed their warranty claims.

165 Securities Exch. Comm'n, Waste Management Founder, Five Other Former Top Officers Sued for Massive Fraud, http://www.sec.gov/news/headlines/wastemgmt6.htm/.

${ }^{166}$ Patricia M. Dechow, Weili Ge, Chad R. Larson \& Richard G. Sloan, Predicting Material Accounting Misstatements, 28 CONTEMP. ACCT. RES. 17, 20 (2011).

${ }^{167}$ Sadka, supra note 81 , at 461 .

168 Karthik Balakrishnan \& Daniel A. Cohen, Product Market Competition and Financial Accounting Misreporting, at 26, available at http://ssrn.com/ abstract=1927427/.

${ }^{169}$ Sadka, supra note 81 , at 441. 
industries to both overinvest and to misrepresent their financials. ${ }^{170}$ As fraud firms report record profits and growth, honest rivals follow the perceived industry trend. ${ }^{171}$ Similarly, providers of capital rely on the perceived growth during a boom and pour money into firms without adequately assessing whether present and future profits are real or not. ${ }^{172}$ Second, very few product markets are in fact perfectly competitive. And finally, most firms operate in multiple product markets, some of which might be competitive while others concentrated, which further dampens the market constraint of competition.

\section{e. Other Costs}

Finally, fraud distorts government policy, reduces the tax base, and harms communities.

Government often bases policy on required disclosures. Sidak argues that WorldCom's fraud distorted government policy, in addition to wreaking havoc on the firm's rivals. ${ }^{173}$ Quoting former FCC Chairman Michael K. Powell, Sidak notes that federal and state governments use disclosures to set regulatory fees, determine interstate access charges for telecommunications, set rates for unbundled services, evaluate whether the division of federal-state jurisdiction is proper, and perform many other activities. $^{174}$

When fraud results in business exit or reduces profits and incomes, all levels of government suffer from reduced tax revenues and increased demand for social spending. A large firm's failure or retrenchment causes disproportionate impacts on the community in which it is located. After Enron declared bankruptcy and several other local companies reported fraud, Houston, an otherwise prosperous and growing city, experienced a recession that was both longer and deeper than the national recession. ${ }^{175}$ Houston's unemployment rate, which is generally lower than the national average, increased in early 2002 (Enron declared bankruptcy in December

170 See Gerard Hoberg \& Gordon Phillips, Real and Financial Industry Booms and Busts, 65 J. FIN. 45 (2010) (finding that firms in competitive industries face coordination problems and overinvest in capacity during industry booms); Tracy Yue Wang \& Andrew Winton, Competition and Corporate Fraud Waves, available at http://ssrn.com/abstract=1783752/.

${ }^{171}$ Wang \& Winton, supra note 170 , at 23-24.

${ }^{172}$ Id.

${ }^{173}$ See Sidak, supra note 89, at 236-37.

${ }^{174}$ Id. at 236.

175 Greater Houston Partnership, The ECONOMY AT a Glance: Houston 1 (Oct. 2011), available at http://www.houston.org/pdf/research/eag.pdf/. 
2001) and remained between 0.5 and 1 percent above the national average until late 2006. ${ }^{176}$ The Houston economy is dependent on oil prices and rises and falls with the price of crude. From 2000 to 2006, the price of crude tripled, and so Houston should have boomed. ${ }^{177}$

\section{Determinants of the Social Cost's Magnitude}

Not all accounting frauds are created equal. Some firms are more likely to misrepresent their performance than others, and some financial misrepresentations are more harmful than others. This section briefly explains what factors increase the likelihood that a firm will commit fraud. It then analyzes what factors might increase the social welfare effects of each occurrence of fraud.

\section{Likelihood of Fraud}

The observed prevalence of fraud produces a biased estimate of its actual prevalence, and there is evidence that many frauds go undetected. ${ }^{178}$ Nevertheless, some observations are worth noting. Larger firms are more likely to face an SEC enforcement action for earnings manipulation: the largest $10.0 \%$ of firms by market capitalization accounted for $14.7 \%$ of SEC enforcement actions for fraud between 1982 and 2005, while the smallest decile featured in $5.1 \%$ of accounting and auditing enforcement releases ("AAERs"). ${ }^{179}$ Greater visibility and scrutiny might explain more detection among the larger firms, but their ability to afford the best auditors should mitigate against fraud in the first place.

Firms in growth industries, like computer software and hardware, retail and services, and those with substantial investments in intangible assets also are more likely to commit accounting fraud than firms in stable industries with substantial fixed assets (such as refining or utilities). ${ }^{180}$ Firms with high $\mathrm{P} / \mathrm{E}$ ratios, those seeking to raise new capital and those where

176 See Greater Houston Partnership, Economic Development, Work Force, http://www.houston.org/economic-development/facts-figures/workforce/index.aspx/ (last visited Oct. 24, 2011).

177 The price of crude went from (inflation adjusted) $\$ 22.30$ per barrel in 1999 to $\$ 65.03$ per barrel in 2006. Inflationdata.com, Historical Crude Oil Prices, http://inflationdata.com/inflation/inflation_rate/historical_oil_prices_table.asp/ (last visited Feb. 20, 2012).

${ }^{178}$ Joseph Gerakos \& Andrei Kovrijnykh, Reporting Bias and Economic Shocks, Aug. 1, 2010, http://ssrn.com/abstract=1546478/ (finding that on average, 17-20\% of firms with sufficient data on COMPUSTAT exhibit significant earnings manipulation).

${ }^{179}$ Dechow et al., supra note 166 , at $32 \&$ tbl.2A.

${ }^{180} I d$. at $32 \&$ tbl.2B, 34 . 
managers' pay is more closely-linked to stock-price performance relative to rivals' performance also are more likely to misstate their financials. ${ }^{181}$

Finally, economists generally believe that product market competition should reduce the firms' proclivity for fraud because it reduces agency costs, ${ }^{182}$ but the relationship "is not as easy to formalize as one might think." ${ }^{183}$ Wang and Winton find evidence that there is a kernel of truth to the notion: firms in competitive industries during periods of normal growth are generally about half as likely as their peers in concentrated industries to commit fraud. ${ }^{184}$ The effect is most pronounced in those competitive industries where financial statements are highly comparable: each firm's disclosure provides information about other firms' financial disclosures. ${ }^{185}$ If a manager misrepresents the firm's earnings, outsiders can more easily detect that the disclosure is false by comparing it with the disclosures of honest rivals. ${ }^{186}$

During periods of growth, however, the propensity of oligopolies for fraud remains unchanged, while in competitive industries the likelihood of fraud quadruples (as compared with its normal rate), and exceeds that of firms in concentrated industries. ${ }^{187}$ Periods of growth eliminate the constraints that competitive product markets ordinarily impose. The combination of easy money and a need for external financing to increase capacity creates a powerful incentive to misrepresent financials. ${ }^{188}$ Misrepresentations that paint a rosier picture than true further spur overinvestment in capacity. The bust that inevitably follows exposes both

${ }^{181}$ Id. at 42; Wang \& Winton, supra note 170, at 27-29. This observation casts doubt on Bebchuk and Fried's proposal that stock options be indexed to better align managers' incentives with those of the shareholders. See LuCian BEBChuK \& JESSE FrIED, PAY Without PERFormance: THE Unfulfilled Promise OF EXECUTIVE COMPENSATION (2004).

182 See Milton Friedman, Essays In Positive Economics (1953); Xavier Giroud \& Holger M. Mueller, Does Corporate Governance Matter in Competitive Industries?, 95 J. FIN. ECON. 312 (2010) (showing that protections from hostile takeovers reduce market value of firms in concentrated industries, but not of those in competitive industries, suggesting that product market competitions disciplines management); K.J. Martijn Cremers, Vinay B. Nair \& Urs Peyer, Takeover Defenses and Competition: The Role of Takeovers, 5 J. EMP. LEGAL STUD. 791 (2008) (reporting similar findings).

${ }^{183}$ Bengt R. Hölmstrom \& Jean Tirole, The Theory of the Firm, in HANDBOOK OF Industrial ORganization, Volume I (R. Schmalensee \& R. D. Willig, eds., 1989) (cited in Balakrishnan \& Cohen, supra note 168 , at $3 \&$ n.2).

${ }^{184}$ Wang \& Winton, supra note 170.

${ }^{185}$ Balakrishnan \& Cohen, supra note 168, at 5, 12.

${ }^{186} \mathrm{Id}$. at 3-4.

${ }^{187}$ Wang \& Winton, supra note 170 , at $39 \&$ tbl.3.

${ }^{188} I d$. at 21. 
the fraud and the overinvestment, leading to business failure and significant distortion in product markets as well as markets for productive inputs. ${ }^{189}$

\section{Size of the Distortion from Fraud}

Several factors affect the costliness of each financial misrepresentation: (a) size, duration and type of the misrepresentation; (b) characteristics of the fraud firm, and (c) characteristics of the markets in which the fraud firm operates.

\section{a. Fraud Characteristics}

A number of studies suggest that duration affects the social cost of fraud: the longer fraud remains undetected, the greater the distortion. ${ }^{190}$ Even though a single-period misrepresentation can inflate the stock price substantially, persistent misrepresentations distort economic decisions more. $^{191}$

$\mathrm{Yu}$ and $\mathrm{Yu}$ find evidence that firms' political spending delays discovery of fraud. They report that fraud persists longer and is less likely to be detected if the firm lobbies that if it does not. Moreover, they find that firms spend more on lobbying while the fraud is ongoing, both, compared with non-fraud lobbying peers and compared with their own lobbying expenditures before fraud. ${ }^{192}$

The type of the misrepresentation matters also. Rivals, suppliers, and large customers are more likely to use and rely on a misstatement of core

${ }^{189}$ The internet and telecommunication booms are recent examples. An older example includes railroads: extensive miles of track were laid (including spurs to future towns not yet built) by firms in the railroad industry only to be followed by numerous bankruptcies in the late $1870 \mathrm{~s}$ See Illinois Railroad Boom, 1865-73, http://www.eslarp.uiuc.edu/ibex/archive/ vignettes/rrboom.htm. The Chicago Sun Times wrote in 1872 that wealth from the railroads "will so overflow our coffers with gold that our paupers will be millionaires. .." Id.

190 See Brown \& Angus, supra note 91, at 28 (observing that persistent fraud is far more damaging than intermittent fraud); Park, supra note 114, at 550 (using fundamental analysis to argue that persistent misstatements ought to be presumptively material).

${ }^{191}$ Cf. William Kinney et al., Earnings Surprise "Materiality" as Measured by Stock Returns, 40 J. ACCT. RES. 1297, 1310 (2002) (finding that the consequences of missing an earnings target by one cent vary widely, depending on context).

${ }^{192}$ Frank Yu \& Xiaoyun Yu, Corporate Lobbying and Fraud Detection, J. FIN. \& QUANT. ANAL. (forthcoming) (finding that lobbying firms evade fraud detection 117 days longer, and are $38 \%$ less likely to be detected by regulators; and that they spend $77 \%$ on lobbying that non-fraud firms and $29 \%$ more during fraud periods than during non-fraud periods), available at http://ssrn.com/abstract=954368/. 
accounts, such as revenues, sales, market share, and cost of goods sold, than on the firm's pension fund returns.

The size of the misrepresentation, and not just its duration or type, increases the distortion, but the correlation is weaker. ${ }^{193}$ A quantitatively large financial misstatement can substantially inflate the value of the company and distort capital and labor market allocation, as well as the firm's product market decisions. The discovery of fraud immediately causes the stock price to fall substantially, lenders to accelerate their loans, and customers to flee, which might lead to insolvency. ${ }^{194}$ The large size also suggests that management was aware of the misstatement, further increasing the capital-market penalty, and causing a larger post-fraud adjustment in business activities. ${ }^{195}$ The notion that large frauds are worse than small frauds produced the rule-like quantitative standard that a financial misstatement is immaterial unless it misrepresented net income by more than five percent. ${ }^{196}$ (That standard has since been replaced with a qualitative standard for materiality of a financial misstatement.) ${ }^{197}$

\section{b. Fraud Firm Characteristics}

Relative firm size affects the social cost of financial misrepresentations. Rivals are more likely to rely on and copy dominant firms' behavior than they are to copy smaller firms, including their business and investment decisions as well as their accounting practices. ${ }^{198}$ Similarly, accounting fraud in concentrated industries is more likely to distort rivals' economic behavior. ${ }^{199}$ Fraud in industries with low barriers to entry will encourage inefficient business entry, increasing the social cost from fraud. ${ }^{200}$ Finally,

193 The SEC's Staff Accounting Bulletin No. 99 reflects the notion that while size of the misstatement matters, small misstatements can also have significant effects. SEC Staff Accounting Bulletin No. 99, 64 Fed. Reg. 45,150, 45,151 (1999).

${ }^{194}$ Park, supra note 114, at 553.

195 See id. at 554 (suggesting that when misstatements are large, it is more likely that management was aware of them, or at least should have been aware).

196 See Matthew J. Barrett, The SEC and Accounting, in Part Through the Eyes of Pacioli, 80 Notre DAME L. REV. 837, 874 (2005) ("As a general rule, accountants and auditors usually treat any amount which does not exceed five percent of income before taxes as immaterial.").

197 See SEC Staff Accounting Bulletin No. 99, 64 Fed. Reg. 45,150, 45,152 (1999) (noting that "[q]ualitative factors may cause misstatements of quantitatively small amounts to be material").

${ }^{198}$ See Gleason et al., supra note 121, at 103-04 (finding that competitors' stock prices decline significantly when the restating firm is large, but show no effect so when the restating firm is small); Wang \& Winton, supra note 170, at 2.

199 See Balakrishnan \& Cohen, supra note 168 , at 9.

${ }^{200} \mathrm{Id}$. 
the cost to non-shareholders is greater if the firm files for bankruptcy, in particular if the firm was otherwise viable.

\section{c. Market Characteristics}

The effect of competition in the markets for inputs and outputs on the social cost of fraud is complicated. ${ }^{201}$ Product market competition affects the likelihood that a firm's managers will commit fraud. ${ }^{202}$ Many rivals in an industry also reduce the likelihood that fraud by any single firm distorts substantially economic decisions by rivals, but fraud by a non-negligible number of rivals would produce a distortion, just like fraud by a single firm in a concentrated industry. ${ }^{203}$ In addition, market concentration affects the size of the distortion from fraud as fraud firms change their pricing and output. $^{204}$

Fraud can also affect the size of the product market itself and can either increase demand for the particular good or service, or decrease it. Demand for audit, legal, and consulting services often increases after financial scandals. Demand for other goods and services might decrease, in correlation with the slowed (or negative) rate of economic growth and higher rates of unemployment that sometimes follow financial scandals.

The more interesting effect of competition is that it affects who ultimately bears the cost of fraud. The conventional wisdom assumes that investors as residual owners bear the bulk of the cost of fraud. But this conclusion is true only for firms in truly competitive industries, and in truly competitive, perfectly informed, and frictionless markets for labor, capital, and products. In all other cases - the vast majority - fraud firms and their rivals are able to shield their profits (and their stock price) and pass along the cost of business shocks from the more competitive market for securities to the relatively less competitive markets for inputs and outputs. ${ }^{205}$

Peress finds support for the relative competitiveness hypothesis in the product markets: firms use market power to pass on shocks to customers and insulate profits. ${ }^{206}$ Kedia and Philippon show that rivals shift some of

${ }^{201}$ See discussion above in Part II.C.1.

${ }^{202}$ Wang \& Winton, supra note 170 , at $39 \&$ tbl.3.

${ }^{203}$ See supra at note Error! Bookmark not defined. and accompanying text.

${ }^{204}$ It is worth repeating that competitive markets behave like concentrated markets during investment booms or bubbles. See discussion supra in Part II.B.2.d.

${ }^{205}$ Cf. Andrei Shleifer \& Lawrence H. Summers, Breach of Trust in Hostile Takeovers, at 34, in Corporate TAKeOvers: CAUSES AND Consequences (Alan J. Auerbach ed. 1988) (observing that firms can transfer rents from employees to shareholders).

${ }^{206}$ See Peress, supra note 132, at 4-5. See also Annie Gasparro, Starbucks Bumps Up Prices, WALl ST. J., Jan. 4, 2012, at B2 (reporting that the firm's customers were less 
the post-disclosure cost of fraud onto employees, ${ }^{207}$ and Files and Gurun suggest that the lack of product market competition enables borrowers to negotiate better terms than their peers in more competitive industries. ${ }^{208}$

Finally, as the studies cited in Part II indicate, it would be wrong to argue that a few bad apples cause the bulk of the social cost of fraud and that accounting fraud is rarely costly for non-shareholders. Most studies report median losses and overall losses to restating firms and their competitors, not just losses in aberrant cases like Enron or WorldCom. While it is true that Enron caused greater harm than fraud in, say, SeaView Video Technology, Inc. - a firm with 20 employees that overstated its earnings by $\$ 1.8$ million $^{209}$ - the studies demonstrate that even (mere) restatements cause real economic harm to non-shareholders.

\section{MisSING THE BIGGER PICTURE}

As recently as 2003, Lev observed that no-one has tackled the important issue of what "social harm is caused by earnings manipulations," 210 even though it is "undoubtedly very consequential." 211 If the central premise adopted by commentators is so obviously wrong, why has no-one noticed it? Why is there still a $\$ 20$ bill lying on the sidewalk for this author to pick it up? A combination of history and intellectual path dependence, a change in the nature of securities fraud, and disciplinal blindness is the culprit.

\section{A. History}

The Securities Exchange Act of 1934, which prohibits accounting fraud in the secondary markets, responded to a particular abuse of the late 1920s. At the time, Congress understood the crash of 1929 to have been caused by market manipulation, and so the newly drafted laws focused on one identified problem and reached a specific, and narrow, conclusion about

sensitive to price increases than its rivals and so the firm decided to raise prices of brewedcoffee to offset higher costs caused by futures contracts for coffee-in other words, to shield investors from its market misjudgment by passing along the cost to its customers).

${ }^{207}$ See supra note 156 and accompanying text.

${ }^{208}$ See Files \& Gurun, supra note 135, at 21-22.

209 U.S. Gen. ACC'T OfFice, FinAnCial StATEMEnt Restatements: Trends, MARKET IMPACTS, REgUlatory RESPONSES, AND REMAINING CHALlENGES 192 (2002), available at http://www.gao.gov/new.items/d03138.pdf/.

${ }^{210}$ Lev, supra note 63, at 42.

${ }^{211}$ Id. at 44. 
solutions. $^{212}$ The Securities Act of 1933, the Exchange Act, and the newlycreated SEC aimed to prevent investors from being "unfairly robbed of their investments." 213 Framed as corrective justice, Section 13 of the Exchange Act requires public firms to disclose information to investors at regular intervals. ${ }^{214}$ Complementing Section 13, Section 10(b) of the Exchange Act prohibits making fraudulent statements in connection with securities trading, and authorizes the SEC to pursue violators. ${ }^{215}$

By 1934, that interpretation is hardly the only, or even most reasonable, conclusion about the harm from the 1929 stock-market crash. Given the economic dislocation of the Great Depression, New Deal lawmakers could have focused on the macroeconomic impact of disruption to financial markets. The financial sector exists to channel savings to firms. Distortions in these markets disrupt that process and weaken allocative efficiency. Therefore, the utmost concern of regulation would be in preserving capital markets as conduits of the lifeblood of the economy, and regulate them as a utility. $^{216}$

Alternately, lawmakers could have adopted a retributive approach and focused on the wrongdoers. They could have concluded that it is immoral for the dishonest to benefit from their misdeeds, and decided that the purpose of government is to reward virtue and punish vice. In that universe, one can imagine yet another set of laws that largely ignored whether fraud inflicted any harm, against whom, and how much.

But, the Exchange Act did not adopt retribution or allocative efficiency as its raison d'être. Instead, it focused on investor protection and so commentators have studied regulatory changes and new enforcement approaches through that lens. This produced what generously can be called intellectual path dependence: the stated goal of the rules determines how the rules are analyzed, and subsequent commentators respond to the work of those coming before them. In a universe where only investors are harmed by fraud, the really thorny issues (unsurprisingly) revolve around showing

212 See Steve Thel, The Original Conception of Section 10(b) of the Securities Exchange Act, 42 STAN. L. REV. 385, 412-13 (1990) (reporting that "Pecora investigated every aspect of the securities business that promised scandal," but focused on stock pools and manipulative strategies they employed).

${ }^{213}$ Choi \& Guzman, supra note 43 , at 941.

214 15 U.S.C. $\$ 781$ (2010).

21515 U.S.C. $\$ 78 \mathrm{j}(2010)$.

${ }^{216}$ Section 2 of the Fletcher-Rayburn bill that would later become the Exchange Act (after many amendments, including to Section 2) asserted that stock manipulation can cause recessions, and interfere "with the supply of credit, the calculation of taxes, and the proper functioning of financial institutions." Thel, supra note 212, at 426-27. But, ultimately, the basic problems the bill addressed were "speculation and manipulation." Id. at 427 . 
that fraud in fact harmed investors. These issues have generated a series of Supreme Court opinions that first, expanded and then severely limited private rights of action, ${ }^{217}$ spurred a slew of laws and regulations designed to fix the perceived problem, ${ }^{218}$ and produced a rich academic literature analyzing these decisions or proposing new securities laws. ${ }^{219}$

\section{B. The Changed Nature of Securities Fraud}

A second, and complementary, explanation for the scholarship's blind spot is that the nature of securities fraud has changed since the Exchange Act was adopted. Stock pools, secret loans, undisclosed profit-sharing plans, self-dealing contracts, and insider trading, in fact, largely harm investors. $^{220}$ The distortion of real economic decisions caused by the inflated stock price is relatively small.

Unable to self-deal and trade on inside information with impunity, dishonest managers have innovated. Today, accounting fraud is the most common species in the genus of securities fraud and it differs from manipulative stock pools in one important respect. While accounting fraud usually inflates the stock price, the effect is achieved not through managers' stock market activities, but through the release of false information, which affects the stock price indirectly. It is the false disclosure that causes both, the economic distortion and an inflated stock price, while the fraud is ongoing and thereafter. ${ }^{221}$

After the 1930s, the stock market took decades to recover and, when it finally did, it continued to stagnate while the larger economy prospered. Although equities did well in the 1960s, the market really took off in the mid-1980s. The stock-market growth, coupled with managerial incentives that are closely tied to the firms' stock-price and a greater willingness of directors to remove managers for subpar performance, produced a powerful

${ }^{217}$ See id. at 461-64 (arguing that the Supreme Court also has limited substantially the scope of Section 10(b) and Rule 10b-5).

218 Private Securities Litigation Reform Act of 1995, Pub. L. 104-67, 109 Stat. 737 (codified as amended in scattered sections of 15 U.S.C.).

219 See e.g., James Spindler, Why Shareholders Want Their CEOs to Lie More After Dura Pharmaceuticals, 95 GEO. L.J. 653 (2007); Pritchard, Stoneridge, supra note 53, at 217; Rose, Reforming Securities Litigation, supra note 69.

${ }^{220}$ William O. Douglas, Directors Who Do Not Direct, 47 HARV. L. REV. 1305, 1306 (1934) (describing manipulative techniques employed in the late 1920s).

221 Earlier scholarship suggested that stock prices by themselves "influence the production, distribution, and consumption of goods and services in the economy." Lynn A. Stout, The Unimportance of Being Efficient: An Economic Analysis of Stock Market Pricing and Securities Regulation, 87 MICH. L. REV. 613, 616 (1988). 
incentive to manage earnings and misrepresent the financial health of the firm. ${ }^{222}$

As the nature of securities fraud has changed from market manipulation to financial misrepresentations, the nature of the social harm that fraud causes also has changed. As Part II elaborates in greater detail, financial misrepresentations produce costs even if not a single share changes hands during the fraud period. ${ }^{223}$ Because stock trading is highly liquid and transactions frequent, there will always be some shareholders who are harmed when a firm misreports its performance. But the focus on investors and their losses has limited the scope of analysis, as well as the universe of both, tools available to regulators and remedies to those injured by accounting fraud. ${ }^{224}$

\section{Blinders of the Discipline}

Empirical investigation and the consequent theoretical implications are driven by data availability. Stock prices are readily available and thus often studied; opportunity costs to employees much less so. The dearth of studies may have led economists and legal academics alike to assume that the costs of distortions to non-shareholders are small and to rely on the stock price as the correct measure of the social welfare effects of fraud. ${ }^{225}$

Nevertheless, the broader economic effects of fraud in Enron, WorldCom and their sisters-in-crime have been widely discussed in the

${ }^{222}$ See Keith J. Crocker \& Joel Slemrod, The Economics of Earnings Manipulation and Managerial Compensation, 38 RAND J. ECON. 698, 700 (2007) (observing that "compensation contracts contingent on reported earnings cannot provide managers with the incentive both to maximize profits and to report those profits honestly").

${ }^{223}$ If no individual sold or bought stock during the fraud period, no securities violation under Section 10(b) and Rule 10b-5 occurs - and thus no accounting fraud. See Blue Chip Stamps v. Manor Drug Stores, 421 U.S. 723, 730-31 (1974) (affirming the rule first adopted in Birnbaum v. Newport Steel Corp., 193 F.2d 461 (9th Cir. 1952) that a person who is neither a purchaser nor a seller of securities may not bring an action under $\S 10$ (b) of the Securities Exchange Act).

${ }^{224}$ See e.g., Statement of the Securities and Exchange Commission Concerning Financial Penalties, Jan. 4, 2006, http://www.sec.gov/news/press/2006-4.htm/ (suggesting that the agency will not seek civil penalties from firms in cases where shareholders did not benefit from fraud, but were instead its victims).

${ }^{225}$ Cf. Shleifer \& Summers, supra note 205, at 34 (noting that it is incorrect to measure the "efficiency gains from takeovers by looking at event study measures of increases in shareholder wealth"); K.J. Martijn Cremers, Vijay B. Nair \& Chenyang Wei, Governance Mechanisms and Bond Prices, 20 REV. FIN. STUD. 1359 (2007) (finding that policies that benefit shareholders will not necessarily benefit bondholders, and might on net harm them). 
media, ${ }^{226}$ and even by the SEC. ${ }^{227}$ Perhaps Enron and WorldCom were perceived as outliers and not representative of the sample of all misreporting firms. Or, even if commentators accepted the fact that frauds destroy more than just equity, they usually noted that regulation aimed at preventing fraud imposes cost on all firms, honest and dishonest. While the notion is accurate, it is incomplete: fraud, too, imposes costs on honest firms (and their stakeholders) through resource misallocation and contagion. But just like stock-price declines after fraud, the costs of compliance with regulation designed to prevent fraud are very visible, in particular to corporate managers. The cost of resource misallocation and contagion, however, would be very difficult to calculate: one would need to know the counterfactual in the absence of fraud. And so, it is easier to attribute a stock-market decline, tighter credit, and unemployment to the business cycle rather than fraud.

Economic modeling, a popular economic method frequently used by securities law scholars, further exacerbates the tendency to underestimate the cost of fraud. While it is a useful analytical tool, economic modeling has a serious limitation: if a variable is missing from the model or if the value assigned to it is incorrect (e.g., assigning zero value to variables that are difficult to estimate), ${ }^{228}$ the model will produce a result that is wrong. The more complex the system studied, the greater the risk of omission or error. The effects of financial misrepresentations are broad, varied, and often difficult to quantify precisely, and our understanding of the workings of a complex and dynamic system like the economy quite limited.

Finally, academics may be experts in their field, but are often unaware of the work of other disciplines (or even sub-fields within the same discipline). For example, efforts to define independence as it pertains to corporate directors, administrative agencies, and central banks have occupied scholars in these different areas for decades, yet there has been no

${ }^{226}$ Public upset surrounding Enron was significant and occupied the nation for a long time. Larry Ribstein reported that commentators on his blog wrote things like "I hope [Ken] Lay[, the former CEO of Enron,] is burning in hell," "Lay certainly did do more harm than a murderer," and "Lay certainly caused billions of dollars of people's pensions to disappear." Larry E. Ribstein, The Perils of Criminalizing Agency Costs, 2 J. BUS \& TECH. L. 59, 64 (2007).

${ }^{227}$ See Glassman, supra note 7 (highlighting the fact that misleading disclosures result "directly and indirectly in a serious misallocation of resources").

${ }^{228}$ See e.g., Ctr. for Biological Diversity v. Nat'l Highway Safety Comm'n, 538 F.3d 1172, 1200-01 (9th Cir. 2008) (chiding the NHTSA for assigning zero value to benefits from reduced carbon emissions resulting from more stringent CAFÉ standards because of the difficulty estimating such benefits, despite recognizing that reduced emissions confer substantial benefits on the economy). 
cross-pollination between them. ${ }^{229}$ "Lessons learned through decades of research in one field can be lost to those struggling with the same concepts in another." ${ }^{, 230}$ Similarly, it appears that securities law scholars have missed the lessons about fraud that accounting scholars have learned over the last decade.

\section{IMPLICATIONS}

Financial misrepresentations impose social cost above and beyond that suffered by shareholders of the fraud-committing firm because they (1) distort that firm's decisions as managers try to mask their fraud; (2) interfere with rivals' ability to learn from fraud firm's disclosures; (3) induce socially-wasteful investments by creditors, employees, and other stakeholders (such as vendors, suppliers) while fraud is ongoing; (4) produce contagion and a costly adjustment to new information after fraud is unmasked; and (5) cause bankruptcies. The cost of false disclosures is not borne only by investors as securities laws assume. Rather, most victims of accounting fraud lack remedies under existing law.

Combined, these five claims lead to several tentative conclusions for fraud regulation and enforcement. Accurate disclosures have characteristics of a public good, and so public regulation is preferable to private ordering. Harms caused by false disclosures are dispersed, and thus public enforcement is preferable to private rights of action and market solutions. Much of the analysis that follows is a thought experiment, and specific recommendations are beyond the scope of this Article.

The study on the social cost of financial misrepresentations also sheds light on and breathes new life into the mostly dead debate about shareholder primacy. If fraud produces costs external to the fraud firm, than improved corporate governance alone cannot further the public interest. The Article does not quibble with the conclusion of shareholder primacy proponents that managers should run firms in the interest of shareholders. But, it favors significantly more aggressive public regulation and enforcement of fraud, (and of other corporate activities that harm non-shareholders) than do proponents of shareholder primacy.

\section{A. Implications for Fraud Prevention, Regulation, and Enforcement}

${ }^{229}$ Peter Conti-Brown \& Ronald J. Gilson, The Limits of Independence in Institutional Design, at 6 (on file with author) (providing a unified field theory of independence).

$$
{ }^{230} \text { Id. at } 6 \text {. }
$$


First, false disclosures cause intra-firm harms to shareholders and nonshareholders, as well as external harms to rivals, suppliers, vendors, distributors, lenders, and their constituents. ${ }^{231}$ Thus, reforms to corporate governance that are designed to empower shareholders are destined to disappoint as fraud-prevention tools because shareholders lack the proper incentives to implement optimal disclosure and compliance mechanisms. ${ }^{232}$ Shareholders can partly self-insure against the firm-specific risk of fraud by diversifying their holdings. They reap the rewards before fraud is unmasked as their firms cement "dominant positions in rapidly expanding, lucrative markets." Only if the fraud is exposed, do they lose part of their investment, but their downside risk is limited and largely diversifiable. ${ }^{233}$ Often, they can shift at least some of the cost of fraud onto others. ${ }^{234}$

In both Enron and WorldCom, the poster children for accounting fraud, the harm to shareholders was fairly dispersed. Institutional investors owned most shares, so losses to any individual institution were small and represented only tiny portions of their portfolios. ${ }^{235}$ Employees, particularly those with pensions in Enron stock, rivals, and communities bore much of the risk that they could not diversify away effectively. ${ }^{236}$

Shareholders also suffer from "collective myopia" that makes them focus on the stock price: it is difficult for outside shareholders to gauge whether the firm is making sound, long-term investments, but "easy to see whether the stock price went up today."237 Managers' focus on the short term, sometimes manifesting as financial manipulation, reflects shareholder preferences. And so, increased shareholder power is not the answer to the problem, it "is the problem." 238 The final reason that firm-level fraud

231 The Article uses "constituents" to refer to shareholders and stakeholders, as the latter are defined supra in note 97.

${ }^{232} \mathrm{I}$ am in particular referring to the shareholder-activist-championed provisions in the Dodd-Frank Act of 2010, including proxy access and say-on-pay. See Sections 971 and 951. There is also no evidence that shareholder-nominated directors are any more likely than firm-nominated directors to prevent or uncover accounting fraud that managers work so hard to conceal. See Urska Velikonja, Why Boards Are Poor Monitors? (on file with author).

${ }^{233}$ Donald C. Langevoort, The Social Construction of Sarbanes-Oxley, 105 MicH. L. REV. 1817, 1829 (2007) [hereinafter Langevoort, Social Construction].

${ }^{234}$ See discussion supra in Part II.C.2.c.

${ }^{235}$ Donald C. Langevoort, The SEC, Retail Investors, and the Institutionalization of the Securities Markets, 95 VA. L. REV. 1025, 1066 (2009).

${ }^{236}$ Langevoort, Social Construction, supra note 233, at 1829.

${ }^{237}$ Judith F. Samuelson \& Lynn A. Stout, Are Executives Paid Too Much?, WaLl ST. J., Feb. 26, 2009, at A13 (arguing that executive pay packages are the "over-arching cause" of the financial crisis).

238 William W. Bratton \& Michael L. Wachter, The Case Against Shareholder Empowerment, 158 U. PA. L. REV. 653, 727 (2010). 
prevention tools, such as corporate governance reforms, are destined to disappoint is that the cost of fraud is not contained within the fraud firm, but spreads to other firms and to markets for input and output. Even if firms were to take into account all intra-firm costs of false disclosures (or if the firm's stakeholders could protect themselves effectively through contract), they would be willing to spend less than socially optimal to prevent fraud. ${ }^{239}$

Second, the push to water down fraud regulation and scale back enforcement, motivated by the high cost of compliance for investors is, likewise, misguided. Shareholders are a poor yardstick: if rational, they would prefer that managers commit less fraud than more (but only up to a point). But, if some fraud is inevitable, rational shareholders would prefer that it never be unmasked because they avoid the large reputational penalty that accompanies disclosure. Others however, suffer from greater distortions the longer fraud goes on undetected.

Third, harms from fraud are widely dispersed among many different markets and market participants. As a result, no single private party (or class of private parties) has optimal incentives to prevent fraud: not investors, ${ }^{240}$ not exchanges, ${ }^{241}$ and not analysts and others who trade on information they have gathered. ${ }^{242}$

${ }^{239}$ Investors may want their managers to cheat some (or, in the language of corporate apologia, to be aggressive businessmen), in particular if it benefits them in the short-term. Rivals, on the other hand, would prefer less cheating, in particular if the competitive environment means that they also must cheat to keep up.

${ }^{240}$ See Larry E. Ribstein, Market v. Regulatory Responses to Corporate Fraud: A Critique of the Sarbanes-Oxley Act of 2002, 28 J. CORP. L. 1, 55 (2002) (arguing against public regulation of accounting fraud because shareholders, in particular institutional investors, can press for changes in governance both by direct communication with managers and by making shareholder proposals). See also Joseph W. Yockey, On the Role and Regulation of Private Negotiations in Governance, 61 S.C.L. REV. 171 (2009) (arguing that Regulation FD impedes direct negotiation between shareholders and managers). For a less optimistic view of shareholder negotiations with management, see Urska Velikonja, Negotiating Executive Compensation in Lieu of Regulation, 25 OHIO ST. J. ON DISP. RESOL. 621 (2010).

241 See Paul G. Mahoney, The Exchange as Regulator, 83 VA. L. REV. 1453, 1455 (1997) [hereinafter Mahoney, The Exchange as Regulator] (arguing that the benefits of regulatory competition would best be achieved by devolving more authority to securities exchanges); Pritchard, Markets as Monitors, supra note 80, at 928-29 (arguing that exchanges could enforce anti-fraud rules at lower cost than private litigation or securities regulators).

${ }^{242}$ See e.g., Goshen \& Parchomovsky, supra note 65, at 714. 
Most private parties who suffer from fraud are not able to use contracts effectively. ${ }^{243}$ Contracting is itself costly. Contracts that are not performed immediately require monitoring, in particular where one contracting party controls access to information. While large creditors usually have access to proprietary information about the firm and can charge higher interest rates or demand collateral when the risk of fraud appears higher, ${ }^{244}$ other stakeholders, such as employees and suppliers, may lack the information and the negotiating power to protect themselves adequately. ${ }^{245}$ Many workers find it 'difficult, if not impossible, to verify employers' or potential employers' statements with regard to the safety of the workplace, job security, or certain employment benefits," let alone fraud. ${ }^{246}$ Private sector unions are as weak as they have been since the Gilded Era. ${ }^{247}$ Creditors, large and small, usually can reduce their firm-specific risk of fraud by diversifying, just like investors. Employees, unsecured (i.e., tort), and trade creditors cannot easily diversify. In addition, coordination problems impede contractual remedies by employees and unsecured and trade creditors. Finally, employees or unsecured creditors could demand higher pay, but that will reduce demand for their work and services, and constrict economic activity. $^{248}$

Rivals cannot use contract, but they could, in general, rely less on their peers' financial statements (a costly proposition as reliable information about the business environment is costly to obtain), particularly when those statements appear too good to be true. But that is exactly the problem with accounting fraud. If it is to work, it must be convincing. The best frauds were "successful" precisely because managers were able to fool the many markets in which the firm operated that their statements were truthful, and

243 But see Stephen M. Bainbridge, In Defense of the Shareholder Wealth Maximization Norm: A Reply to Professor Green, 50 WASH. \& LEE L. REV. 1423 (1993) (suggesting that employees can protect their interests either contractually or through regulatory pressure).

${ }^{244}$ Fred Tung has observed that lenders are increasingly active monitors, often more influential than major shareholders, even when the firm is not distressed. Frederick Tung, Leverage in the Board Room: The Unsung Influence of Private Lenders in Corporate Governance, 57 UCLA L. REV. 115, 117 (2009).

${ }^{245}$ Kent Greenfield, The Place of Workers in Corporate Law, 39 B.C.L. REV. 283, 299-303 (1998) [Greenfield, Workers in Corporate Law].

${ }^{246}$ Greenfield, Labor Fraud, supra note 143, at 752.

${ }^{247}$ Only 6.9 percent of private sector workers were unionized in 2010. Overall union membership has been on the decline since the Bureau of Labor Statistics started collecting information in 1983. See U.S. DEP'T OF LABOR, BuREAU OF LABOR STATS., UNION MEMBERS-2010, Jan. 21, 2011. See also Greenfield, Labor Fraud, supra note 143, at 752 (observing in 1997 that unions "are in a period of historical weakness").

${ }^{248}$ Greenfield, Labor Fraud, supra note 143, at 753. 
thus their business decisions worth copying. And even if rivals did doubt a fraud firms' numbers, their own shareholders and market analysts might push them toward fudging their numbers. ${ }^{249}$

If ex ante private ordering is an ineffective tool to internalize the cost of fraud, ex post private remedies are worse. Even if everyone harmed by financial misrepresentations had standing to sue, harm from each incident may be difficult to calculate and prove. Moreover, increasing the number of potential plaintiffs would not increase the pot from which to draw their compensation. Many have criticized the shareholder class action ${ }^{250}$ and this Article joins them in disapproval, but for reasons very different from those usually given: the remedy is limited to the victims best able to self-insure against fraud and least deserving of compensation. ${ }^{251}$ Assuming that the purpose of private actions is not compensation, but deterrence, the securities fraud class action could be justified if shareholders were better monitors than other potential plaintiffs (such as employees or rivals). But, in the one study to date, the authors found that employees reported $19 \%$ of frauds, while shareholders discovered only $3.2 \%$ of frauds. ${ }^{252}$

And fourth, because false disclosures distort markets across state lines, fraud should be regulated and enforced federally (or even internationally),

249 In an environment with low enforcement and high rewards for fraud, all competitors may find it optimal to commit fraud, even though the market overall would be better off if no-one committed fraud.

${ }^{250}$ For criticism and proposed modification of securities class actions, see Alexander, supra note 48, at 1508-14 (proposing that damages be replaced with fines); Arlen \& Carney, supra note 58, at 720 (proposing that firm-level liability be eliminated); Baer, supra note 20, at 1035 (proposing that insurance replace private actions); Bratton \& Wachter, FOTM, supra note 29 (proposing that FOTM be abolished and the SEC step-up its enforcement efforts); John C. Coffee, Jr., Gatekeeper Failure and Reform: The Challenge of Fashioning Relevant Reforms, 84 B.U.L. REV. 301, 349-53 (2004) (proposing shifting liability to auditors); Coffee, Reforming, supra note 20, at 1582-84; Alicia Davis Evans, Investor Compensation Fund, 33 J. CORP. L. 101 (2007) (proposing insurance in lieu of the class action); Langevoort, Capping Damages, supra note 20, at 641-42 (proposing capping damages in securities class actions); Frank Partnoy, Barbarians at the Gatekeepers?: A Proposal for a Modified Strict Liability Regime, 79 WASH. U.L.Q. 491, 540-46 (2001); Pritchard, Markets as Monitors, supra note 80, at 983 (proposing penalties instead of damages to be imposed by exchanges instead of individual plaintiffs); Amanda M. Rose \& Richard Squire, Intraportfolio Litigation, NW. L. REV. (criticizing the securities class action); Rose, Reforming Securities Litigation, supra note 69, at 1301 (proposing that SEC screen securities class actions).

${ }^{251}$ Coffee, Reforming, supra note 20, at 1558 (observing that class actions shift money from shareholders' right pocket to the left one).

252 Alexander Dyck, Adair Morse \& Luigi Zingales, Who Blows the Whistle on Corporate Fraud? 52 \& tbl.2 (CRSP Working Paper No. 618, 2007), available at http://faculty.chicagobooth.edu/finance/papers/who\%20blows\%20the\%20whistle.pdf. 
not at the state level as some have proposed. ${ }^{253}$ Regulatory competition for securities law among states would not produce optimal fraud regulation in a healthy race to the top. ${ }^{254}$ Rather, small states with few local businesses and employees, like Delaware or Nevada, could externalize the cost of fraud onto larger states, while collecting registration fees.

All of these factors suggest that public provision of honest governance through public enforcement and regulation should produce superior outcomes than private ordering and litigation. This Article recognizes that public regulation and enforcement are no panacea. Public agencies usually lack the resources and the political backing needed to regulate and prosecute fraud vigorously. Public enforcement actions remain rare, in particular against large and complex firms. ${ }^{255}$ But, given the nature and the size of the cost of fraud, even massive government failure would likely regulate fraud better than "the market."

Public regulation faces challenges other than politics. The Securities Act and the Securities Exchange Act both invoke the "public interest" as a rationale for regulation, with the goal of "promot[ing] efficiency, competition, and capital formation." 256 The U.S. Supreme Court has only been asked once to interpret that language, and has understood it to refer to competition in securities markets. ${ }^{257}$ Although the Court's decision was predicated on the facts of the case before it, it is unclear in its aftermath that

253 See Roberta Romano, Empowering Investors: A Market Approach to Securities Regulation, 107 YALE L.J. 2359, 2366-67, 2368-69 (1997) (arguing that state competition in securities regulation would allow investors and promoters to select the regime that maximizes their joint welfare) (1997); Mahoney, The Exchange as Regulator, supra note 241 , at 1456 ("Given the difficulty of determining optimal rules, a system of competing markets should do a better job of furthering investor welfare than a system in which a regulator creates and enforces uniform rules.").

${ }^{254}$ Cf. D. Daniel Sokol, Limiting Anti-Competitive Government Interventions That Benefit Special Interests, 17 GEO. MASON L. REV. 119, 123-24 (2009) (arguing that countries may under-regulate and enforce anti-trust laws when anticompetitive practices in one jurisdiction produce spillover effects felt outside the home jurisdiction).

${ }^{255}$ See James D. Cox \& Randal S. Thomas with Dana Kiku, SEC Enforcement Heuristics: An Empirical Inquiry, 53 DUKE L.J. 737, 763, 765 (2003) (observing that fewer than $15 \%$ of firms that settle securities class action also face SEC enforcement action and that average market capitalization of firms targeted by SEC is nearly three times smaller than that of firms named in securities class actions). In 2010 , only $16.7 \%$ of firms sentenced under the federal guidelines had 200 or more employees. See U.S. Sentencing Comm'n, Sourcebook of Federal Sentencing Statistics 2010, at tb1.54, available at http://www.ussc.gov/Data_and_Statistics/Annual_Reports_and_Sourcebooks/2010/Table5 4.pdf/. The report does not disaggregate statistics for fraud nor include deferred prosecution agreements with firms.

${ }^{256} 15$ U.S.C. $\$ \S 77 b(b), 78 c(f)$.

${ }^{257}$ Credit Suisse v. Billing, 551 U.S. 264, 283 (2007). 
the SEC has the authority to regulate to protect non-investors and promote social welfare. ${ }^{258}$

Moreover, it is unclear whether the SEC is the proper regulator and that it is willing to regulate in favor of non-investors, since that would require balancing competing interests of investors and non-investors. But, given the opposition the Consumer Financial Protection Bureau has faced, this Article does not propose creating a separate agency to prosecute fraud with an eye on protecting non-shareholders. Even if a new agency could be created, coordination problems, turf wars and cost might outweigh any benefit of improved fraud deterrence. $^{259}$

Unlike the SEC, there is no doubt under existing law that prosecutors and judges can take into account harms to non-shareholders. Once a defendant has been found or pleaded guilty, the Federal Sentencing Guidelines allow judges to take into consideration total economic harm caused by the offense. ${ }^{260}$ But, criminal enforcement is costly and inevitably rarely used. ${ }^{261}$ Opponents of tough enforcement also argue that draconian criminal sanctions will cause managers to steer clear of potentially lucrative business activities, rendering criminal sanctions necessarily inefficient. ${ }^{262}$ But, complex fraud might be impossible to investigate without the tools available to prosecutors, including wiretaps and cooperation agreements. In particular when levied against individuals, from a strict deterrence

${ }^{258}$ In addition, an enforcement action for securities fraud requires a showing that the firm misrepresented a material fact, and materiality is measured by the significance of the misrepresentation to a reasonable investor. The impediment is perhaps less serious than it appears at first sight: any type of newly released information can move stock prices, including information useful to rivals and other market participants. For the most recent elaboration of the principle, see Matrixx Initiatives v. Siracusano, 131 S.Ct. 1309 (2011).

${ }^{259}$ See Rose, Multienforcer Approach, supra note 39, at 2205 (arguing that double enforcement would make sense when there is an "affirmative reason to think that tougher enforcement is always better"); MAXWELL L. STEARnS \& TODD J. ZYWICKI, PUBLIC CHOICE CONCEPTS AND APPLICATIONS IN LAW, Ch. 6 (noting that double enforcement is justified when agencies target different types of offenses).

${ }^{260}$ U.S. Sentencing Guidelines, §2B1.1(b).

261 See e.g., Darryl K. Brown, The Problematic and Faintly Promising Dynamics of Corporate Crime Enforcement, 1 OHIO ST. J. CRIM. L. 521, 536 (2004) (discussing the difficulties and cost of investigation corporate fraud).

${ }^{262}$ See Daniel R. Fischel \& Alan O. Sykes, Corporate Crime, 25 J. LEGAL STUD. 319, 321 (1996) (concluding that corporate criminal liability in addition to corporate civil liability produces overdeterrence ex ante and excessive investment in litigation ex post, and-if used - "must rest on the need to correct some deficiency in the system of civil liability”); David Zaring, TheConglomerate.org, Why Isn't the SEC Taking Wall Street to Trial?, Dec. 15, 2011, http://www.theconglomerate.org/2011/12/why-isnt-the-sec-takingwall-street-to-trial.html/ ("My normative view, shared by a bunch of law professors, is that it is easy to overcriminalize business conduct and overpolice "fraud" that is really simply a market decline."). 
perspective, criminal sanctions might be the best existing tool we have to fight fraud.

If securities laws could be changed, how should they be changed to reflect the observations put forth in this Article? For one, fraud duration is an important determinant in the size of the social cost of fraud. Any mechanism that would prevent fraud or reduce the lag between the commission of fraud and its unmasking would also reduce the distortion to real economic markets.

For reporting companies, strengthening independent auditing looks like a promising line of defense against fraud. Recently, independent agencies in the United States and the European Union have proposed increasing auditor independence and requiring more detailed and nuanced audit reports. ${ }^{263}$

In addition, severing the agency relationship between management, who selects the auditor, provides information, and pays for the audit, and the auditor ought to reduce the conflict of interest and improve audit quality. ${ }^{264}$ Forensic audits are expensive and time-consuming, but effective. About one-third of firms charged with accounting fraud end in bankruptcy, ${ }^{265}$ and of the firms that file for bankruptcy, about a third is found to have committed fraud before filing. ${ }^{266}$ This suggests that courts reviewing bankruptcy petitions should routinely look for fraud. ${ }^{267}$ In addition, forensic audits could be conducted outside of bankruptcy or scandal, either randomly or when certain red flags are raised. ${ }^{268}$ For example, accounting studies

263 PCAOB, CONCEPT RELEASE ON POSSIBLE REVISIONS TO PCAOB STANDARDS RELATED TO REPOTS ON AUDITED FINANCIAL STATEMENTS AND RELATED AMENDMENTS TO PCAOB StANDARDS, Jun. 21, 2011; EUROPEAN UNION, GREEN PAPER: AUdiT POLICY: LESSONS FROM THE CRISIS, Oct. 13, 2010.

264 Lawrence A. Cunningham, Choosing Gatekeepers: The Financial Statement Insurance Alternative to Auditor Liability, 52 UCLA L. Rev. 413 (2004) (proposing financial statement insurance); Joshua Ronen, Corporate Audits and How to Fix Them, 24 J. ECON. PERSP. 189, 189-90 (2010) (same).

${ }^{265}$ COSO STUDY, supra note 109; Karpoff et al., supra note Error! Bookmark not defined.

${ }^{266}$ DELOITTE FORENSIC CENTER, supra note 109.

267 See e.g., Lehman. But see Kelli Alces, Limiting the SEC's Role in Bankruptcy, 18 AM. BANKR. INST. L. REV. 631 (2010) (arguing that SEC should not investigate and punish bankrupt fimrs).

268 Alm, Jackson and McKee report that IRS tax audits deter tax noncompliance. Forensic accounting audits, likewise, are expected to produce higher quality financial disclosures. Cf. James Alm, Betty R. Jackson \& Michael McKee, The Effects of Communication Among Taxpayers on Compliance, available at http://www.irs.gov/pub/irssoi/04alm.pdf/. 
suggest that certain accounting practices signal fraud, such as high and/or spiking accruals. ${ }^{269}$

As the Article suggests, non-reporting companies' market behavior, if observable, but based on fraud, is also distorting. As noted, the distortion is greater if the firm is large, fraud is long-lasting, and the product market concentrated (or competitive during investment booms). And so, closer oversight is warranted in concentrated industries and during bubbles.

Providing employees and others with incentives to come forward with information about financial misrepresentations also could reduce the duration of fraud. The Sarbanes-Oxley Act adopted fairly anemic whistleblower protections that barred employers from retaliating against whistleblowers. The Dodd-Frank Act of 2010 went further and authorized monetary awards for whistleblowers whose tips lead to a successful SEC enforcement action. ${ }^{270}$ While promising, the whistleblower must jump through many hoops to collect anything. First, the award is conditional on the SEC successfully pursuing the enforcement action. SEC has a long history of neglecting whistleblower tips. More importantly, the agency is always starved for resources. It has recently announced that it would delay establishing an office to handle whistleblower claims because of resource constraints. $^{271}$ Since employees often have better access to information about fraud than others, and discover and report it frequently even without incentives, even more robust incentives than the Dodd-Frank whistleblower awards are warranted. ${ }^{272}$

Finally, the elements of liability for securities fraud could be modified to facilitate enforcement. For example, the standard of care for financial disclosures under the Exchange Act could be changed from recklessness to negligence (akin to Sections 11 or 12(a)(2) of the Securities Act), allowing a public agency to initiate an enforcement action whenever it believed a firm failed to live up to that standard. Given the nature of ripple effects from fraud, however, shareholders' right of action should not be expanded-if anything, it should be limited in exchange for more public

${ }^{269}$ COSO STUDY, supra note 109 , at 45 (noting that revenue fraud is consistently the most common variety of accounting fraud).

${ }^{270}$ Pub. L. No. 111-203, § 922(a), 124 Stat. 1841 (2010). The SEC has since adopted rules implementing the statutory provision. See 17 C.F.R. Part 240 and 249 (providing for a reward when the enforcement action yields a monetary sanction of $\$ 1,000,000$ or more).

271 See http://www.pomtalk.com/pomtalk/2011/03/from-the-pages-of-the-pomerantzmonitor-new-whistleblower-provisions-stir-debate.html/.

${ }^{272}$ Dyck, Morse \& Zingales, supra note 252, at 52 \& tbl.2 (finding that employees discover $19 \%$ of frauds, more than any other group, including financial regulators, auditors, and analysts). 
enforcement as Bill Bratton and Michael Wachter recently proposed, or given to employees. ${ }^{273}$

Although legislative change is unlikely, modifications to securities laws that do not primarily aim to protect investors are not without precedent. ${ }^{274}$ As Professor Langevoort observed, the Sarbanes-Oxley Act "refused shareholders any more governance power, either in terms of voting rights . . or private litigation." 275 Instead, according to Langevoort, the SarbanesOxley Act was motivated by "social and economic dislocation, not simply investor losses," and its requirements for effective compliance mechanisms and independent directors reflect that concern. ${ }^{276}$

Fraud regulation might have "perverse unintended consequences" that some of its detractors fear. ${ }^{277}$ But, the cost of these consequences must be weighed against the true social cost of fraud, not just investors' losses. Finding the right amount of regulation depends on knowing the unknowable - the social cost of prevented frauds - but this Article suggests that the balance ought to be in favor of more regulation and enforcement rather than less.

\section{A. Implications for Competing Theories of the Firm}

By the end of the 1990s, a consensus developed among academic, business, and governmental elites in dominant jurisdictions that corporate managers should run corporations exclusively in the economic interest of the shareholders, ${ }^{278}$ which ended the decades-long debate initiated by Adolf Berle and Merrick Dodd. ${ }^{279}$ Others interested in the enterprise, including creditors, suppliers, employees, and customers can protect their interests

${ }^{273}$ Bratton \& Wachter, FOTM, supra note 29.

274 The Foreign Corrupt Practices Act is another example of legislation that furthers the public interest at the expense of the shareholder interest, as are antitrust laws. Pub. L. No. 95-213, 91 Stat. 1494 (1977) (codified as amended in scattered sections of 15 U.S.C.).

${ }^{275}$ Langevoort, Social Construction, supra note 233, at 1829.

276 Id. at 1828 .

277 Roberta Romano, Regulating in the Dark, Dec. 18, 2011, http://ssrn.com/ abstract $=1974148 /$.

${ }^{278}$ See e.g., Henry Hansmann \& Reinier Kraakman, The End of History for Corporate Law, 89 GEO. L.J. 439, 439 (2000) (suggesting that shareholder primacy is the dominant theory of the corporation and is unlikely to be unseated by any competing theory).

${ }^{279}$ E. Merrick Dodd, Jr., For Whom Are Corporate Managers Trustees?, 45 HARV. L. REV. 1145 (1932); A. A. Berle, Jr., Corporate Powers as Powers in Trust, 44 HARV. L. REV. 1049 (1931); A. A. Berle, Jr., For Whom Corporate Managers Are Trustees: A Note, 45 HARV. L. REV. 1365 (1932). For a recent account, see William W. Bratton \& Michael L. Wachter, Shareholder Primacy's Corporatist Origins: Adolf Berle and the Modern Corporation, 34 J. CORP. L. 99 (2008). 
contractually or through regulation, not by participating in corporate governance. $^{280}$ Not only would shareholder primacy lead to superior corporate governance, but would also maximize social welfare: everyone is better off if managers run firms for the benefit of the shareholders.

Not everyone agrees with the dominant view: notably Kent Greenfield, Margaret Blair, and Lynn Stout have advocated for a broader view of corporate management's duties, including to bondholders, creditors, employees, and communities. ${ }^{281}$ Greenfield argues that workers as workers (and because their pension is invested in corporate stock) ought to have a role in director elections, and that corporate directors should owe workers fiduciary duties. ${ }^{282}$ Blair and Stout take an even broader view, arguing that corporate directors ought to govern for all corporate constituents that makefirm specific investments, including shareholders and stakeholders. ${ }^{283}$

While sympathetic to the progressive view, this Article suggests that neither side is right. Shareholder primacy proponents argue that nonshareholders protect themselves with contracts and regulation. But, rivals and their constituents have no contractual relationship with the fraud firm and thus cannot use contracts to protect themselves against the cost of fraud in other firms. Moreover, the political process has produced remedies for fraud that are costly, but neither very effective at fraud deterrence nor at compensating the victims (but lucrative for lawyers and elites): securities class actions and independent boards. Investor-centric ideology has weakened public institutions to the point that they are ridiculed for failure. ${ }^{284}$ Progressives, on the other hand, proposed that the interests of non-shareholders be protected within the firm: corporate boards ought to take into account employees and other firm constituents in governance. But progressives, too, do not include rivals and their constituents as factors in decision-making. Any firm-centric governance solution will necessarily produce too much fraud.

${ }^{280}$ Hansmann \& Kraakman, supra note 278 , at 440-41.

281 See Margaret M. Blair \& Lynn A. Stout, A Team Production Theory of Corporate Law, 85 VA. L. REV. 247, 254, 300-01 (1999); Kent Greenfield \& D. Gordon Smith, Debate: Saving the World with Corporate Law?, 57 EMORY L.J. 947, 965-66 (2008) (discussing Professor Greenfield's rejection of shareholder primacy); Lyman Johnson, New Approaches to Corporate Law, 50 WASH. \& LEE L. REV. 1713, 1716-17 (1993); David Millon, Communitarians, Contractarians, and the Crisis in Corporate Law, 50 WASH. \& LEE L. REV. 1373, 1376-77 (1993).

${ }^{282}$ Greenfield, Workers in Corporate Law, supra note 245, at 287.

${ }^{283}$ Blair \& Stout, supra note 281, at 300-01.

${ }^{284}$ See Allan Chernoff, Sr., Madoff Whistleblower Blasts SEC, CNNMoney.com, Feb. 4, 2009, http://money.cnn.com/2009/02/04/news/newsmakers/madoff_whistleblower/. 
Instead of placing inordinate trust into the hands of firms, their managers and directors, this Article advocates that we recognize that honest governance is a public good, to be reinforced through public means.

\section{CONCLUSION}

The prevailing model for assessing the social cost of financial misrepresentations limits its scope to the costs suffered by investors. Since investors as a class can self-insure through diversification against the firmspecific risk of fraud, their net losses approximate zero, unless the frequency of fraud increases over time. Capital market efficiency may suffer, but, again, the harm from accounting fraud is usually small, because capital market efficiency does not depend on who owns shares in any given firm.

This Article aims to redirect the debate to a more complete understanding of social cost. Unlike stock price manipulations that divert equity from one firm to another, financial misrepresentations mislead rivals, creditors, vendors, suppliers, and employees, all of whom rely on financial disclosures in making economic decisions. False disclosures distort real markets, including those for debt and labor, and product markets. Empirical evidence suggests that the social cost of financial misrepresentations to nonshareholders is substantial and ought to be taken into account in both, regulation and enforcement. Because the social cost of financial misrepresentations is significant and the harm dispersed among a variety of stakeholders and firms, public enforcement actions (including imposing criminal sanctions) against fraud-committing managers, coupled with strengthened early detection mechanisms, may ultimately prove to be the most effective and efficient mechanism for bringing the levels of fraud to socially optimal. 